\title{
Stereoselective Synthesis of the Spirocyclic $\gamma$-Lactam Core of the Ansalactams
}

Zhanhao Liang, You-Chen Lin and Joshua G. Pierce*

Department of Chemistry and Comparative Medicine Institute, NC State University, Raleigh, North Carolina, USA

E-mail: jgpierce@ncsu.edu

\section{Supporting Information}

Table of Contents

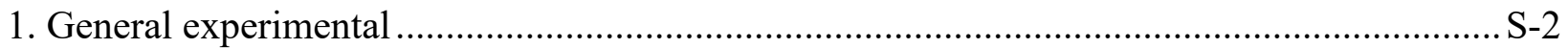

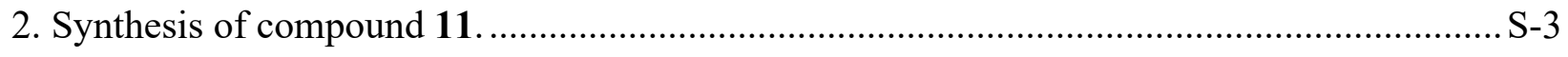

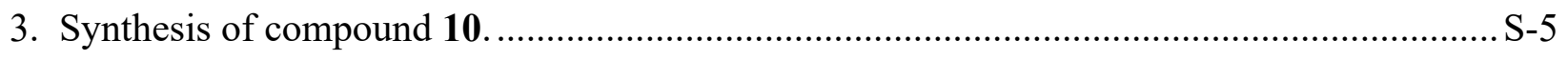

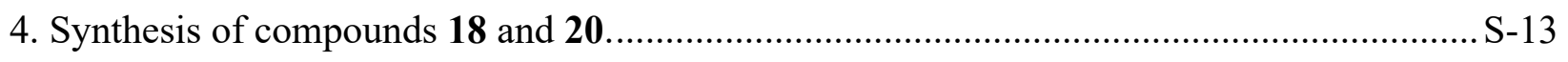

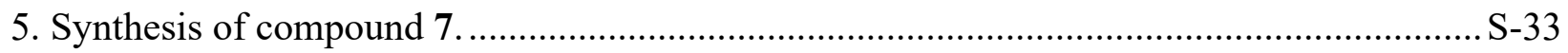




\section{General experimental}

General experimental procedures: All reactions were carried out under an inert argon atmosphere with anhydrous solvents under anhydrous conditions unless otherwise stated. All reactions, except those conducted in the presence of water were carried out in flame-dried apparatus. Heated reactions were performed using an oil bath. Yields refer to chromatographically yield, unless otherwise stated. Reactions were monitored by thin layer chromatography (TLC) analysis (pre-coated silica gel 60 F254 plates, $250 \mathrm{~mm}$ layer thickness) and visualization was accomplished with a $254 \mathrm{~nm}$ UV light and by staining with $\mathrm{KMnO}_{4}$ solution $\left(1.5 \mathrm{~g}\right.$ of $\mathrm{KMnO}_{4}, 10$ $\mathrm{g}$ of $\mathrm{K}_{2} \mathrm{CO}_{3}$, and $1.25 \mathrm{~mL}$ of a $10 \% \mathrm{NaOH}$ solution in $200 \mathrm{~mL}$ of water) with heating. Reactions were also monitored by LC-MS (2.6 mm C18 50 x $2.10 \mathrm{~mm}$ column). Flash chromatography on $\mathrm{SiO}_{2}$ was used to purify the crude reaction mixtures and performed on a Biotage Isolera utilizing Biotage cartridges and linear gradients. Diastereomeric ratio was determined by crude ${ }^{1} \mathrm{H}$ NMR spectroscopy.

Materials: Tetrahydrofuran (THF) and dichloromethane $\left(\mathrm{CH}_{2} \mathrm{Cl}_{2}\right)$ were obtained by passing the previously degassed solvents through activated alumina columns under nitrogen atmosphere. Deuterated solvents (containing 0.03 to 0.05 vol \% tetramethylsilane, TMS) were purchased from Cambridge Isotope Laboratories. All other reagents were purchased from commercial chemical companies and used without further purification, unless otherwise stated.

Instrumentation: Infrared spectra were determined on the Agilent Cary 630 FTIR spectrometer and data are represented as frequency of absorption $\left(\mathrm{cm}^{-1}\right)$. Melting points were determined on the Thomas Hoover capillary melting point apparatus and data are represented as temperature $\left({ }^{\circ} \mathrm{C}\right)$. ${ }^{1} \mathrm{H}$ and ${ }^{13} \mathrm{C}$ NMR spectra were obtained on a 500,600 or $700 \mathrm{MHz}$ instrument in $\mathrm{CDCl}_{3}$ unless otherwise noted. 1D NOE spectra were used to aid structure assignments when necessary. Chemical shifts $(\delta)$ were reported in parts per million $(\mathrm{ppm})$ with the residual solvent peak used as an internal standard $\left(\mathrm{CDCl}_{3}{ }^{1} \mathrm{H} \mathrm{NMR}=7.26 \mathrm{ppm},{ }^{13} \mathrm{C} \mathrm{NMR}=77.16 \mathrm{ppm}\right)$ and multiplicities are reported as observed. The following abbreviations were used to explain NMR peak multiplicities: $\mathrm{s}=$ singlet, $\mathrm{d}=$ doublet, $\mathrm{t}=$ triplet, $\mathrm{q}=$ quartet, $\mathrm{p}=$ pentet, $\mathrm{dd}=$ doublet of doublets, $\mathrm{m}=$ multiples, $\mathrm{br}=$ broad. Low resolution mass spectra were obtained using electrospray ionization (ESI). Highresolution mass spectra were obtained on a high-resolution mass spectrometer - the Thermo Fisher Scientific Exactive Plus MS, a benchtop full-scan Orbitrap ${ }^{\mathrm{TM}}$ mass spectrometer - using Heated Electrospray Ionization (HESI). The NC state small molecule X-ray facility collected and analyzed all X-ray diffraction data. 


\section{Synthesis of compound $\mathbf{1 1}$.}<smiles>CCOC(=O)/C=C/Cc1ccc(C)c(OC)c1</smiles>

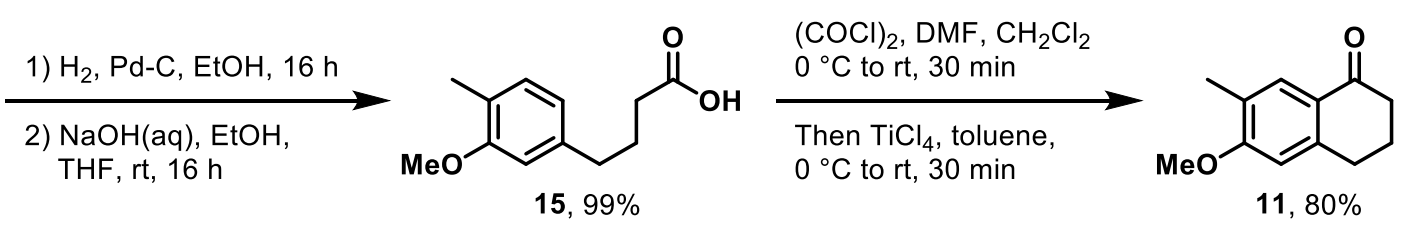

Compound $11^{1,2}$ was prepared using reported synthetic method.

$\boldsymbol{R}_{\mathbf{f}}=0.35$ (1:3, ethyl acetate:hexanes).

${ }^{1}$ H NMR $(500 \mathrm{MHz}, \mathrm{CDCl} 3) \delta=7.73(\mathrm{~s}, 1 \mathrm{H}), 6.54(\mathrm{~s}, 1 \mathrm{H}), 3.79(\mathrm{~s}, 3 \mathrm{H}), 2.82(\mathrm{t}, J=7.5 \mathrm{~Hz}, 2$ H), 2.49 (t, $J=7.5 \mathrm{~Hz}, 2 \mathrm{H}), 2.11$ (s, $3 \mathrm{H}), 2.04-1.99$ (p, $J=6.5 \mathrm{~Hz}, 2 \mathrm{H})$.

(1) Kumar, P. Synthesis of substituted 1-tetralones. Org. Prep. Proced. Int. 1997, 29, 477-480.

(2) Kurata, H., Kusumi, K., Otsuki, K., Suzuki, R., Kurono, M., Komiya, T., Hagiya, H., Mizuno, H., Shioya, H., Ono, T., Takada, Y., Maeda, T., Matsunaga, N., Kondo, T., Tominaga, S., Nunoya, K., Kiyoshi, H., Komeno, M., Nakade, S., Habashita, H. Discovery of a 1-Methyl-3,4dihydronaphthalene-Based Sphingosine-1-Phosphate (S1P) Receptor Agonist Ceralifimod (ONO4641). A S1P $\mathrm{P}_{1}$ and $\mathrm{S}_{1} \mathrm{P}_{5}$ Selective Agonist for the Treatment of Autoimmune Diseases. J. Med. Chem. 2017, 60, 9508-9530. 


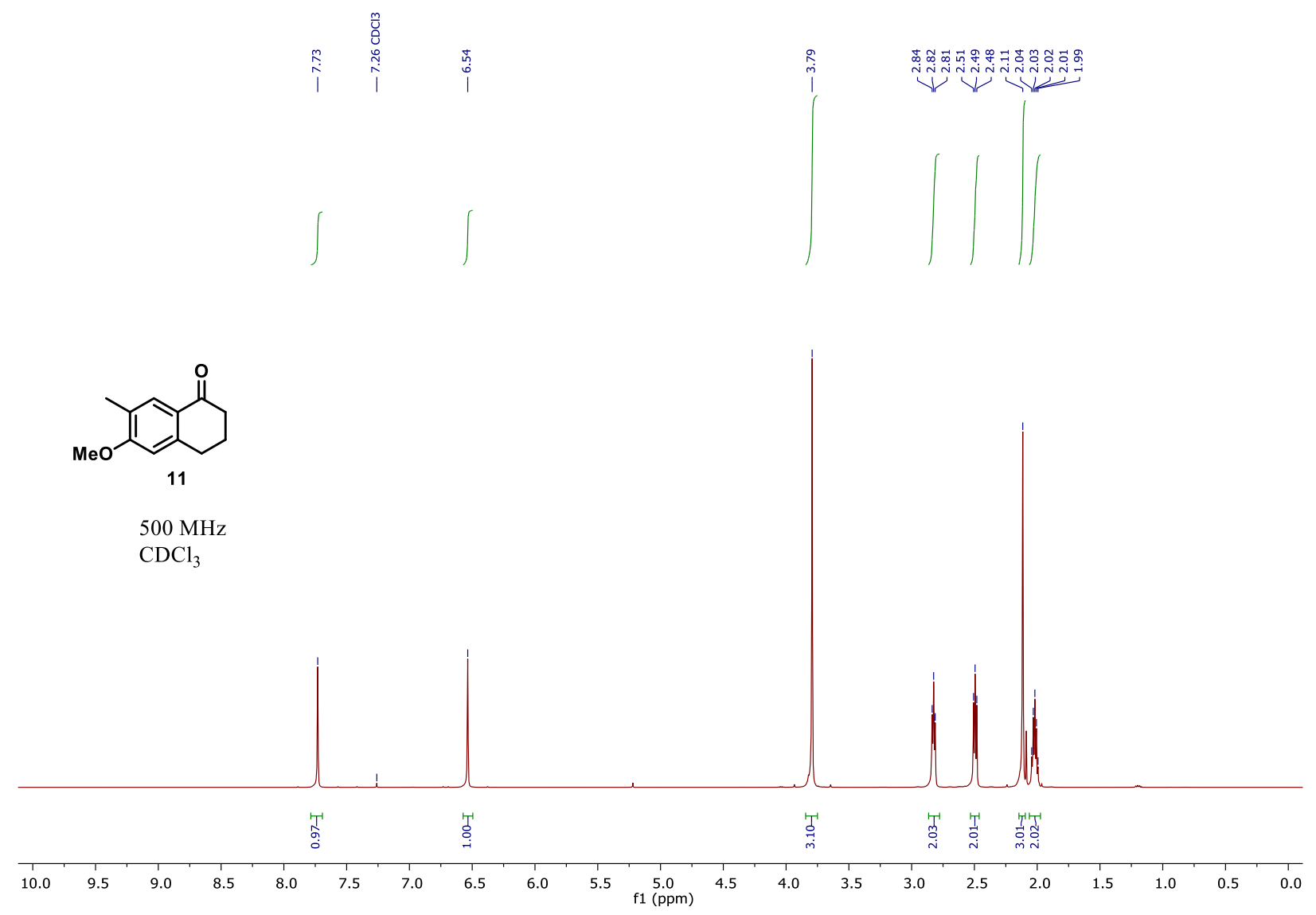




\section{Synthesis of compound $\mathbf{1 0}$.}

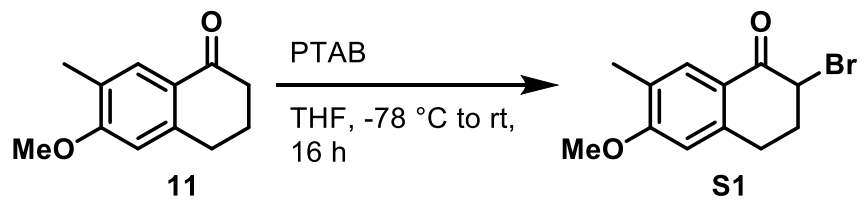

Compound S1: To a solution of $\alpha$-tetralone 11 (9.16 g, $48.2 \mathrm{mmol})$ in anhydrous THF (200 mL) was added a solution of phenyltrimethylammonium tribromide (19.0 g, $50.6 \mathrm{mmol})$ in THF (50 $\mathrm{mL}$ ) at $-78{ }^{\circ} \mathrm{C}$. After stirring at $-78{ }^{\circ} \mathrm{C}$ for $4 \mathrm{~h}$, the reaction mixture was moved to $\mathrm{rt}$ for another 12 $\mathrm{h}$. The mixture was filtered and concentrated under reduced pressure. The crude product was purified by flash chromatography on silica gel (5-10\%, ethyl acetate:hexanes) to yield the product S1 (12.8 g, 99\% yield at 90\% purity), based on the proton NMR, it contains $\sim 10 \%$ byproduct, as an orange oil:

$\boldsymbol{R}_{\mathbf{f}}=0.34$ (1:9, ethyl acetate:hexanes).

${ }^{1} \mathbf{H}$ NMR $\left(500 \mathrm{MHz}, \mathrm{CDCl}_{3}\right) \delta=7.80(\mathrm{~s}, 1 \mathrm{H}), 6.60(\mathrm{~s}, 1 \mathrm{H}), 4.62(\mathrm{t}, J=4.5 \mathrm{~Hz}, 1 \mathrm{H}), 3.85(\mathrm{~s}, 3$ $\mathrm{H}), 3.25-3.18(\mathrm{~m}, 1 \mathrm{H}), 2.84-2.78(\mathrm{~m}, 1 \mathrm{H}), 2.48-2.35$ (m, $2 \mathrm{H}), 2.14$ (s, $3 \mathrm{H})$.

${ }^{13}$ C NMR $\left(125 \mathrm{MHz}, \mathrm{CDCl}_{3}\right) \delta=189.6,162.6,143.6,130.6,126.3,122.5,108.8,55.6,50.8,32.2$, $26.3,15.8$.

IR (Diamond-ATR, neat) $\tilde{\mathrm{V}}_{\max }\left(\mathrm{cm}^{-1}\right): 2917,1674,1595,1495,1341,1253,1119,1046,918,891$, $843,736,668$.

HRMS $(m / z)$ : calculated for $\mathrm{C}_{12} \mathrm{H}_{14} \mathrm{BrO}_{2}[\mathrm{M}+\mathrm{H}]^{+}$269.0172, found 269.0174. 


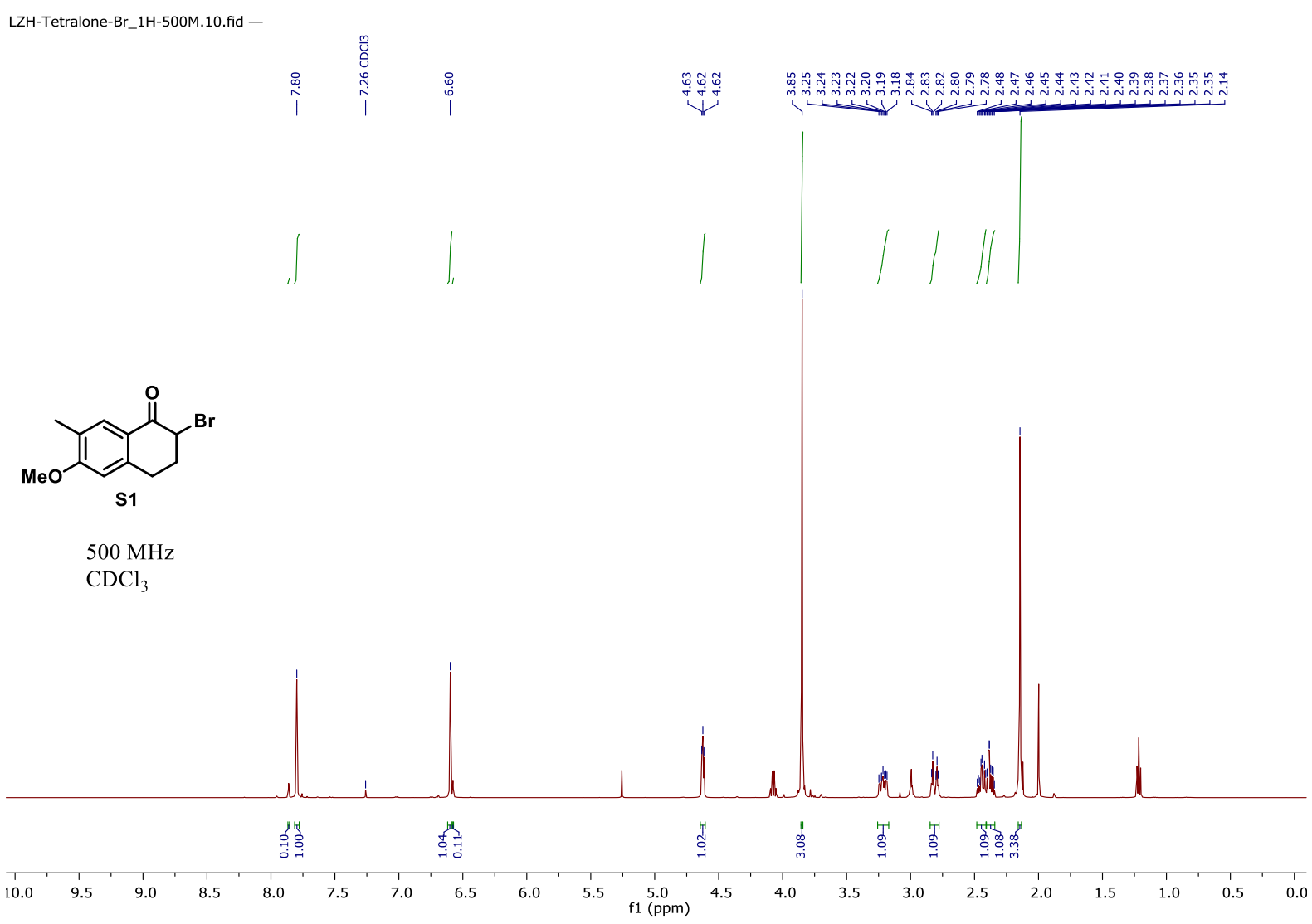

LZH-Tetralone-Br_13C-500M.12.fid -

(

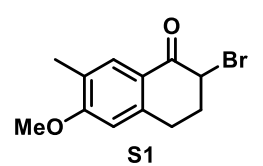

$125 \mathrm{MHz}$

$\mathrm{CDCl}_{3}$
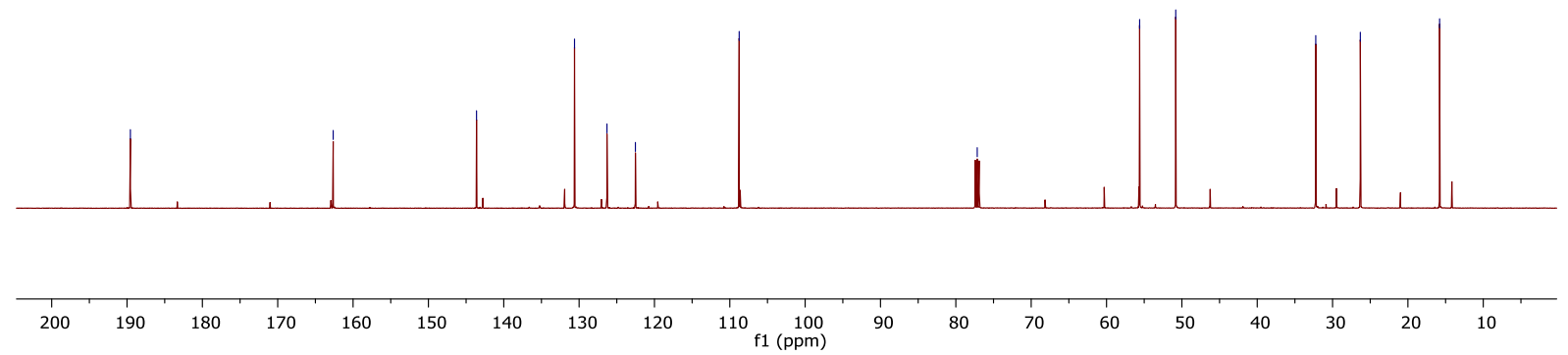


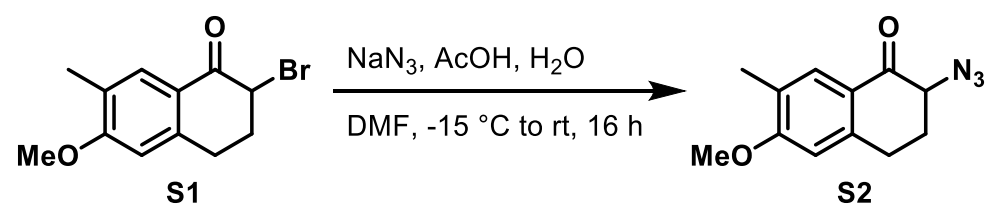

Compound S2: To a solution of $\mathbf{S 1}(11.7 \mathrm{~g}$, $43.5 \mathrm{mmol})$ in DMF (220 mL) was added AcOH (6.28 $\mathrm{mL}, 108 \mathrm{mmol})$ and a solution of $\mathrm{NaN}_{3}(5.65 \mathrm{~g}, 87.0 \mathrm{mmol})$ in $\mathrm{H}_{2} \mathrm{O}(15 \mathrm{~mL})$ at $-15^{\circ} \mathrm{C}$. After stirring at from $-15^{\circ} \mathrm{C}$ to $\mathrm{rt}$ for $16 \mathrm{~h}$, the reaction was quenched by the addition of $\mathrm{H}_{2} \mathrm{O}$. The mixture was filtered and concentrated under reduced pressure. The crude product was purified by flash chromatography on silica gel (5-10\%, ethyl acetate:hexanes) to yield the product $\mathbf{S} 2$ (8.54 g, 85\%) as pale purple solid:

$\boldsymbol{R}_{\mathbf{f}}=0.45$ (1:3, ethyl acetate:hexanes).

Melting point $\left({ }^{\circ} \mathrm{C}\right)=94-96$.

${ }^{1} \mathbf{H}$ NMR $\left(500 \mathrm{MHz}, \mathrm{CDCl}_{3}\right) \delta=7.76(\mathrm{~s}, 1 \mathrm{H}), 6.57(\mathrm{~s}, 1 \mathrm{H}), 4.11\left(\mathrm{dd}, J_{1}=5 \mathrm{~Hz}, J_{2}=10 \mathrm{~Hz} 1 \mathrm{H}\right)$, $3.85(\mathrm{~s}, 3 \mathrm{H}), 2.96\left(\mathrm{dd}, J_{1}=5 \mathrm{~Hz}, J_{2}=10 \mathrm{~Hz}, 2 \mathrm{H}\right), 2.31-2.26(\mathrm{~m}, 1 \mathrm{H}), 2.15(\mathrm{~s}, 3 \mathrm{H}), 2.06-1.98$ $(\mathrm{m}, 1 \mathrm{H})$.

${ }^{13} \mathrm{C}$ NMR $\left(125 \mathrm{MHz}, \mathrm{CDCl}_{3}\right) \delta=192.6,162.6,144.0,129.9,126.2,123.7,108.7,64.0,55.6,29.5$, 27.7, 15.8 .

IR (Diamond-ATR, neat) $\tilde{\mathrm{v}}_{\max }\left(\mathrm{cm}^{-1}\right): 2936,2839,2100,1665,1603,1500,1245,1126,1053,988$, $898,845,767$.

HRMS $(m / z)$ : calculated for $\mathrm{C}_{12} \mathrm{H}_{14} \mathrm{~N}_{3} \mathrm{O}_{2}[\mathrm{M}+\mathrm{H}]^{+} 232.1081$, found 232.1080. 

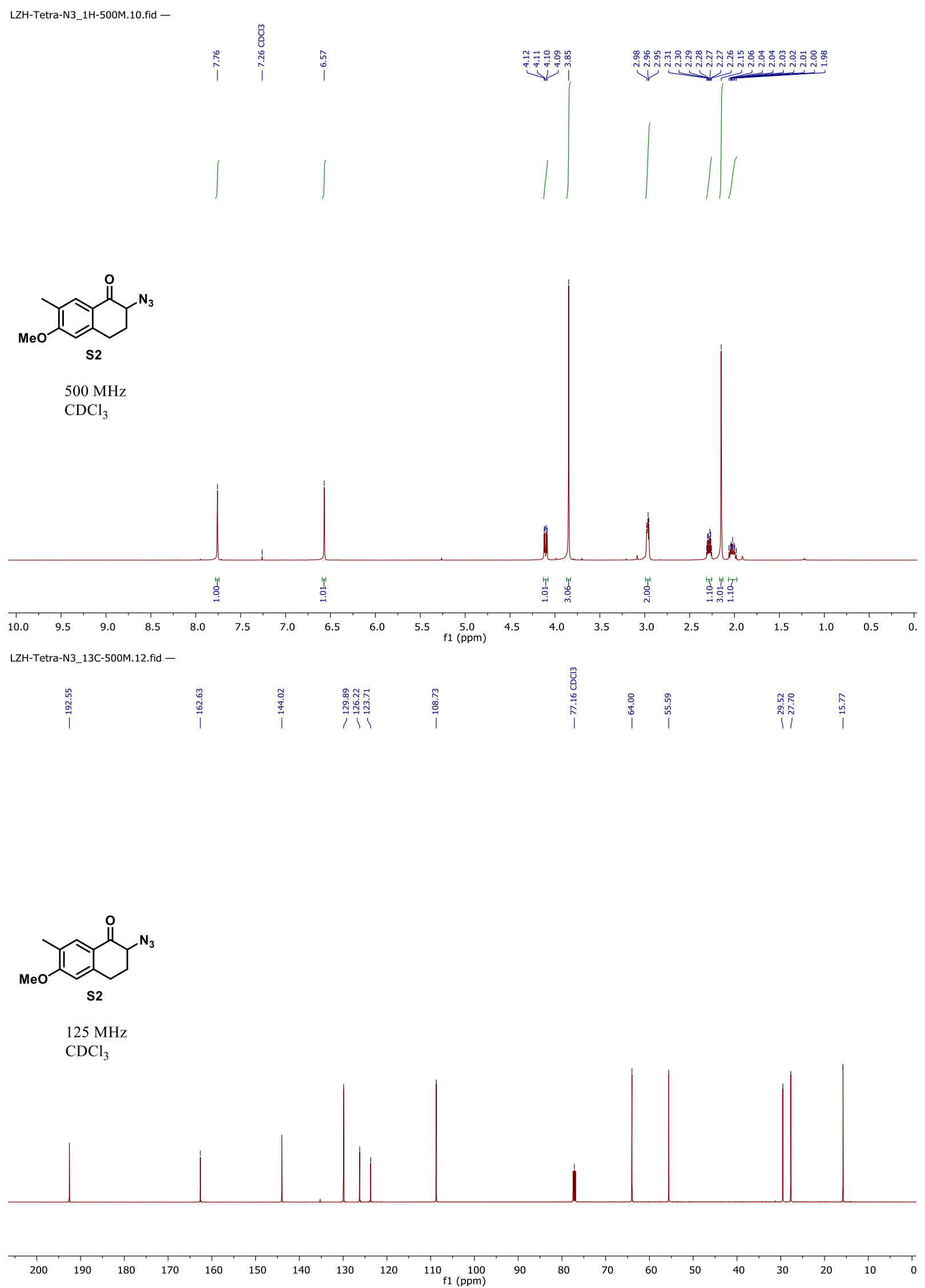


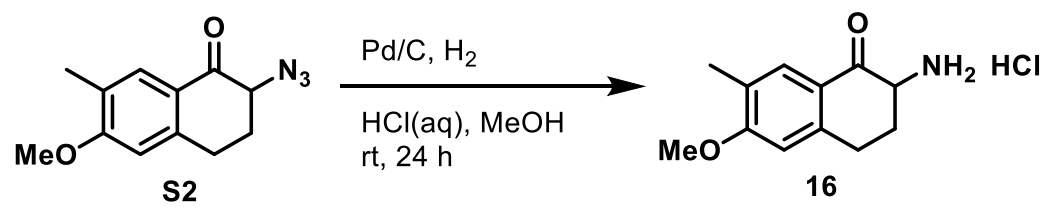

Compound 16: To a solution of $\mathbf{S 2}(8.54 \mathrm{~g}, 36.9 \mathrm{mmol})$ in $\mathrm{MeOH}(190 \mathrm{~mL}), 10 \% \mathrm{Pd} / \mathrm{C}(3.93 \mathrm{~g}$, $3.69 \mathrm{mmol}$ ) was carefully added in one portion under argon atmosphere. After stirring $24 \mathrm{~h}$ at room temperature under $\mathrm{H}_{2}$ (1 atm), reaction was monitored by TLC for full consumption of S2. The mixture was filtered through Celite and concentrated to yield the product $16(7.14 \mathrm{~g}, 80 \%)$ as offwhite waxy solid without further purification:

${ }^{1}$ H NMR (500 MHz, DMSO-d $\left.d_{6}\right) \delta=8.83(\mathrm{br}, 1 \mathrm{H}), 7.69(\mathrm{~s}, 1 \mathrm{H}), 6.91(\mathrm{~s}, 1 \mathrm{H}), 4.24(\mathrm{~d}, J=10.0$ Hz, 1 H), 3.87 (s, 3 H), 3.14 (t, J=10.0 Hz, 1 H), 2.99 (d, J=15.0 Hz, 1 H), 2.52 (br, 1 H), 2.14 (s, $3 \mathrm{H}), 2.12(\mathrm{br}, 1 \mathrm{H})$.

${ }^{13}$ C NMR $\left(125 \mathrm{MHz}, \mathrm{DMSO}-d_{6}\right) \delta=191.5,162.4,145.1,128.7,125.2,123.0,109.8,56.0,54.2$, 27.6, 27.2, 15.6 .

IR (Diamond-ATR, neat) $\tilde{\mathrm{v}}_{\max }\left(\mathrm{cm}^{-1}\right): 3430,3213,2811,1669,1600,1498,1272,1253$.

HRMS $(m / z)$ : calculated for $\mathrm{C}_{12} \mathrm{H}_{16} \mathrm{NO}_{2}[\mathrm{M}+\mathrm{H}]^{+} 206.1176$, found 206.1176. 


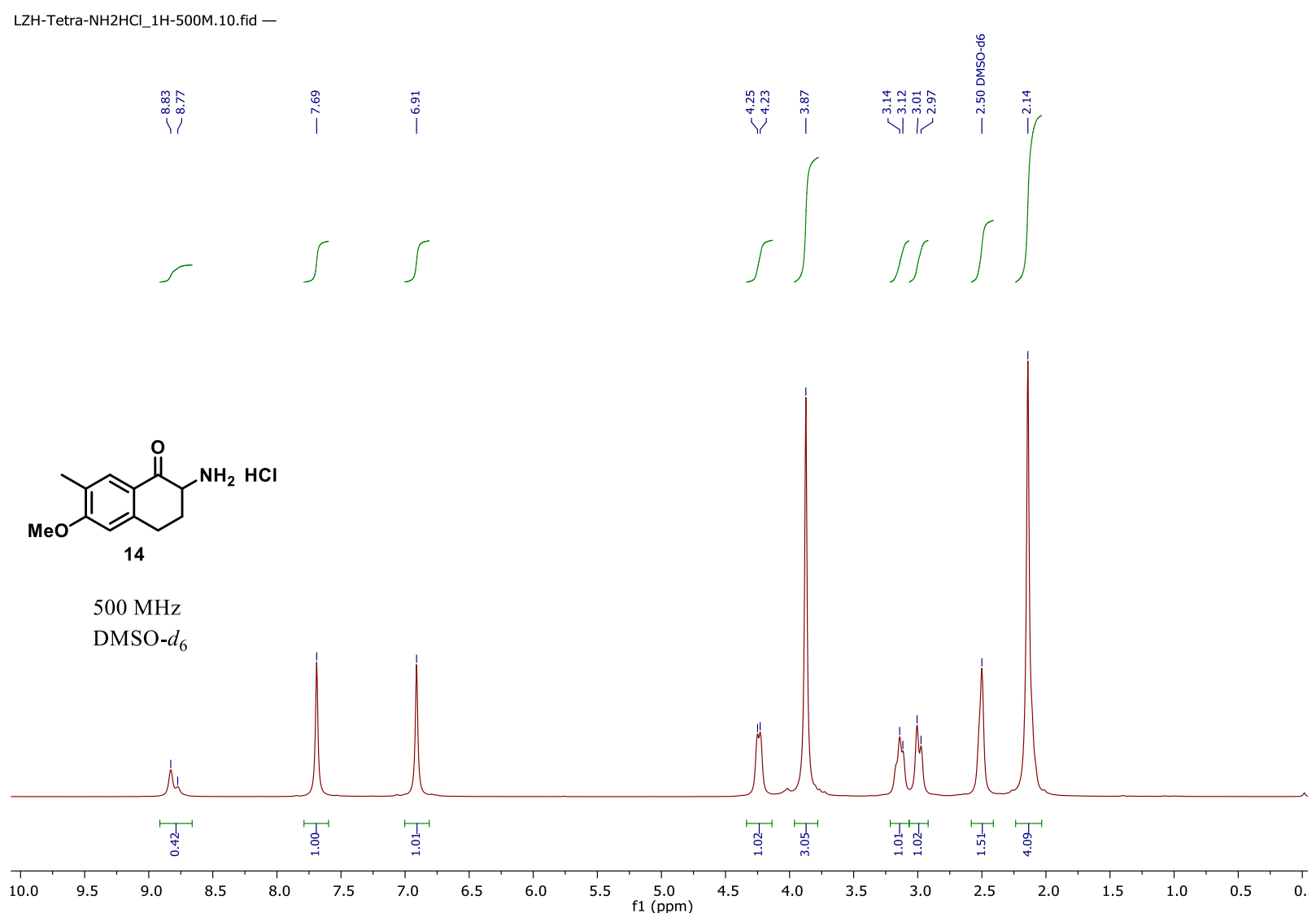

LZH-Tetra-NH2HCl_13C-500M.12.fid -

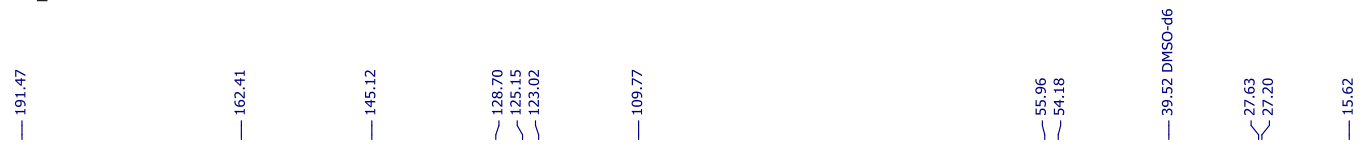

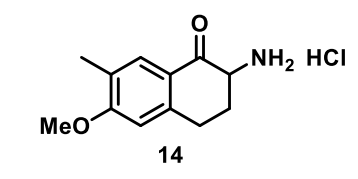

$500 \mathrm{MHz}$

DMSO- $d_{6}$

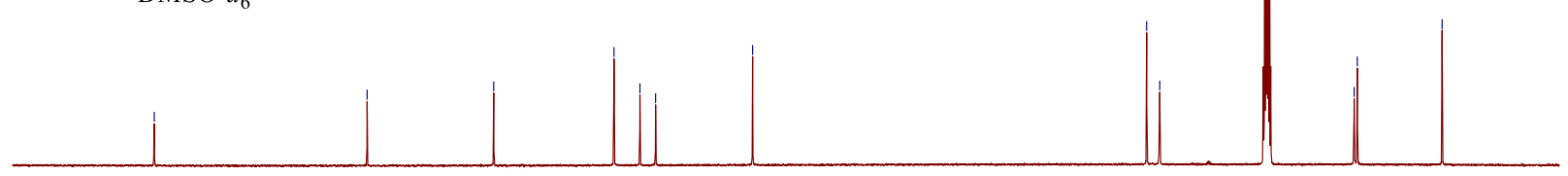

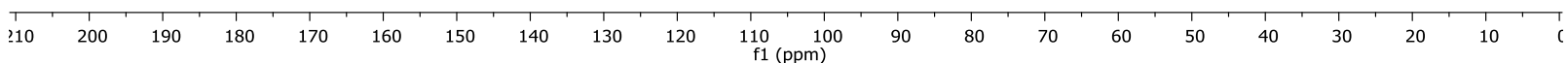




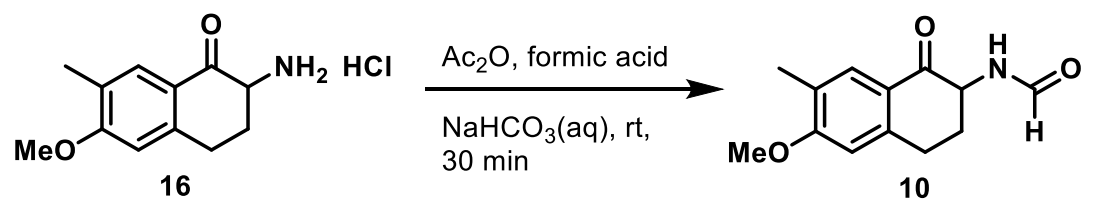

Compound 10: To a flame-dried round bottom flask was added $\mathrm{Ac}_{2} \mathrm{O}(41.4 \mathrm{~mL}, 438 \mathrm{mmol})$ and formic acid $(18.2 \mathrm{~mL}, 482 \mathrm{mmol})$. The reaction was stirred at $60{ }^{\circ} \mathrm{C}$ for $2 \mathrm{~h}$, at which point the mixture was cooled to room temperature and $16(3.00 \mathrm{~g}, 14.6 \mathrm{mmol})$ was added in one portion. To the stirring solution under ambient atmosphere was added $\mathrm{NaHCO}_{3}$ solution $(1.5 \mathrm{M}$ in water, 877 mmol) slowly over $15 \mathrm{~min}$ (The reaction will effervesce violently if the $\mathrm{NaHCO}_{3}$ solution is added too quickly). After the addition of $\mathrm{NaHCO}_{3}$ solution was complete, the reaction mixture was transferred to a separatory funnel and extracted with ethyl acetate $(3 \mathrm{x})$. The organic layers were combined, washed with saturated $\mathrm{NaHCO}_{3}$ (aq) and brine, dried over $\mathrm{Na}_{2} \mathrm{SO}_{4}$, filtered and concentrated under reduced pressure. The crude product was purified by flash chromatography on silica gel (50-75\%, ethyl acetate:hexanes) to yield the product $\mathbf{1 0}(2.56 \mathrm{~g}, 75 \%)$ as a white solid:

$\boldsymbol{R}_{\mathbf{f}}=0.15$ (1:1, ethyl acetate:hexanes).

Melting point $\left({ }^{\circ} \mathrm{C}\right)=150-153$.

${ }^{1}$ H NMR $\left(500 \mathrm{MHz}, \mathrm{CDCl}_{3}\right) \delta=8.32(\mathrm{~s}, 1 \mathrm{H}), 7.79(\mathrm{~s}, 1 \mathrm{H}), 6.84(\mathrm{br}, 1 \mathrm{H}), 6.61$ (s, $\left.1 \mathrm{H}\right), 4.63$ $4.58(\mathrm{~m}, 1 \mathrm{H}), 3.88(\mathrm{~s}, 3 \mathrm{H}), 3.26-3.19(\mathrm{~m}, 1 \mathrm{H}), 2.97-2.92(\mathrm{~m}, 1 \mathrm{H}), 2.86-2.82(\mathrm{~m}, 1 \mathrm{H}), 2.19$ (s, 3 $\mathrm{H}), 1.93-1.85$ (m, $1 \mathrm{H})$.

${ }^{13} \mathrm{C}$ NMR $\left(150 \mathrm{MHz}, \mathrm{CDCl}_{3}\right) \delta=194.1,162.7,161.4,144.4,129.8,126.1,124.0,109.0,55.7$, $55.3,30.7,28.5,15.9$.

IR (Diamond-ATR, neat) $\tilde{V}_{\max }\left(\mathrm{cm}^{-1}\right): 3272,1673,1633,1610,1255,1135,1085,900,850,679$.

HRMS $(m / z)$ : calculated for $\mathrm{C}_{13} \mathrm{H}_{16} \mathrm{~N}_{3} \mathrm{O}_{3}[\mathrm{M}+\mathrm{H}]^{+}$234.1125, found 234.1120. 


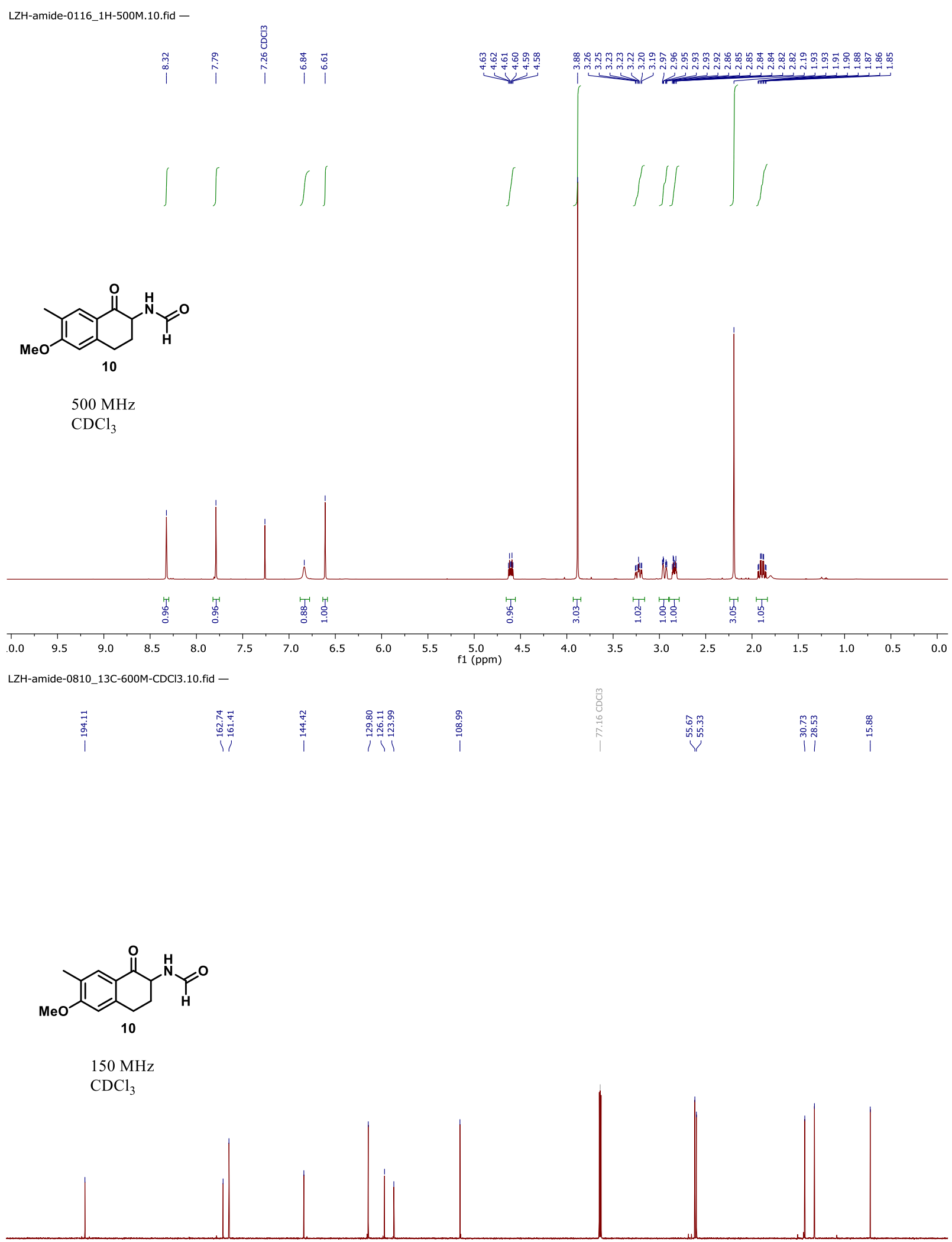

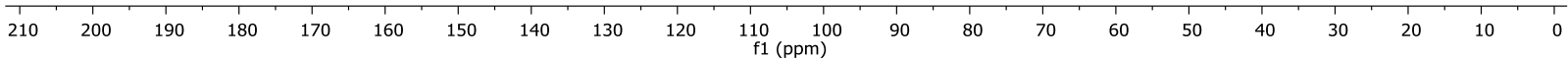




\section{Synthesis of compounds $\mathbf{1 8}$ and $\mathbf{2 0 .}$}<smiles>COc1cc2c(cc1C)C(=O)C(NC(=O)OCC(C)C)CCc1cc(OC)c(C)cc1-c1ocnc1CC2</smiles>

Compound 17: To a flame-dried round bottom flask was added formamide $\mathbf{1 0}(0.25 \mathrm{~g}, 1.07 \mathrm{mmol})$ in anhydrous $\mathrm{CH}_{2} \mathrm{Cl}_{2}(2 \mathrm{~mL})$. The reaction was cooled to $0{ }^{\circ} \mathrm{C}$ and then $\mathrm{Tf}_{2} \mathrm{O}(0.198 \mathrm{~mL}, 1.18$ mmol) was added in one portion. After stirring at $0{ }^{\circ} \mathrm{C}$ for $40 \mathrm{~min}, \mathrm{Et}_{3} \mathrm{~N}(0.030 \mathrm{~mL}, 0.214 \mathrm{mmol})$ and methyl acrylate $(0.194 \mathrm{~mL}, 2.14 \mathrm{mmol})$ were added sequentially, the mixture was stirred at $\mathrm{rt}$ for $16 \mathrm{~h}$. The reaction was monitored by TLC for full conversion of $\mathbf{1 0}$ and quenched by addition of saturated $\mathrm{NaHCO}_{3}(\mathrm{aq})$. The reaction mixture was transferred to a separatory funnel and extracted with $\mathrm{CH}_{2} \mathrm{Cl}_{2}(3 \mathrm{x})$. The organic layers were combined, washed with saturated $\mathrm{NaHCO}_{3}$ (aq) and brine, dried $\left(\mathrm{Na}_{2} \mathrm{SO}_{4}\right)$, filtered and concentrated under reduced pressure. The crude product was purified by flash chromatography on silica gel (40-60\%, ethyl acetate:hexanes) to yield the product $17(0.213 \mathrm{~g}, 65 \%)$ as brown oil:

$\boldsymbol{R}_{\mathbf{f}}=0.21$ (1:1, ethyl acetate:hexanes).

${ }^{1} \mathbf{H}$ NMR $\left(600 \mathrm{MHz}, \mathrm{CDCl}_{3}\right) \delta=7.74(\mathrm{~s}, 1 \mathrm{H}), 7.68(\mathrm{~s}, 1 \mathrm{H}), 6.64(\mathrm{~s}, 1 \mathrm{H}), 3.88(\mathrm{~s}, 3 \mathrm{H}), 3.58(\mathrm{~s}, 3$ $\mathrm{H}), 3.56-3.50(\mathrm{~m}, 1 \mathrm{H}), 3.41(\mathrm{dd}, J=18.0 \mathrm{~Hz}, 1 \mathrm{H}), 2.98-2.92(\mathrm{~m}, 2 \mathrm{H}), 2.88(\mathrm{t}, J=9.6 \mathrm{~Hz}, 1 \mathrm{H})$, 2.82-2.77 (m, $1 \mathrm{H}), 2.22-2.18(\mathrm{~m}, 1 \mathrm{H}), 2.17$ (s, $3 \mathrm{H})$.

${ }^{13} \mathrm{C}$ NMR $\left(150 \mathrm{MHz}, \mathrm{CDCl}_{3}\right) \delta=194.0,172.5,168.2,162.7,145.1,130.4,126.0,124.4,108.9$, $85.1,55.7,52.0,50.8,41.2,36.9,27.2,16.0$.

IR (Diamond-ATR, neat) $\tilde{\mathrm{v}}_{\max }\left(\mathrm{cm}^{-1}\right):$ 2926, 2843, 1734, 1669, 1600, 1258, 1203, 1096.

HRMS $(m / z)$ : calculated for $\mathrm{C}_{17} \mathrm{H}_{20} \mathrm{NO}_{4}[\mathrm{M}+\mathrm{H}]^{+}$302.1387, found 302.1384. 
Note 1: Compound $\mathbf{2 1}$ was formed after $\mathrm{Tf}_{2} \mathrm{O}$ added and reacted with alkene to yield the [3+2] product 17. However, $\mathbf{2 1}$ is air sensitive:

$\boldsymbol{R}_{\mathbf{f}}=0.55$ (1:1, ethyl acetate:hexanes).

LCMS $(m / z)$ : calculated for $\mathrm{C}_{17} \mathrm{H}_{19} \mathrm{NO}_{4}[\mathrm{M}+\mathrm{H}]^{+} 216.1$, found 216 .

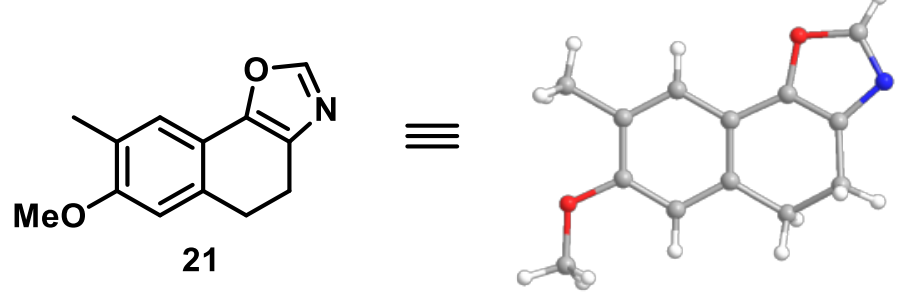

X-ray sample preparation: 21 was prepared as saturated solution in $\mathrm{CH}_{2} \mathrm{Cl}_{2}$ in a $5 \mathrm{~mL}$ scintillation vial. This vial was put into a $20 \mathrm{~mL}$ scintillation vial which contains hexanes as same height level as $\mathrm{CH}_{2} \mathrm{Cl}_{2}$. After the $\mathrm{CH}_{2} \mathrm{Cl}_{2}$ evaporated completely, crystals formed inside of $5 \mathrm{~mL}$ vial. The crystals were a colorless plate-like specimen of $\mathrm{C}_{13} \mathrm{H}_{13} \mathrm{NO}_{2}$, approximate dimensions $0.044 \mathrm{~mm} \times 0.142 \mathrm{~mm} \times 0.183 \mathrm{~mm}$, was used for the X-ray crystallographic analysis. The X-ray intensity data were measured on a Bruker D8 VENTURE system equipped with a Incoatec $\mathrm{I} \mu \mathrm{S} 3.0$ microfocus sealed tube $(\mathrm{Cu} \mathrm{K \alpha}, \lambda=1.54178 \AA)$ and a multilayer mirror monochromator.

The total exposure time was 4.66 hours. The frames were integrated with the Bruker SAINT software package using a narrow-frame algorithm. The integration of the data using an orthorhombic unit cell yielded a total of 50833 reflections to a maximum $\theta$ angle of $80.06^{\circ}$ ( $0.78 \AA$ resolution), of which 2240 were independent (average redundancy 22.693, completeness $\left.=99.9 \%, R_{\text {int }}=2.66 \%, R_{\text {sig }}=0.98 \%\right)$ and $2171(96.92 \%)$ were greater than $2 \sigma\left(\mathrm{F}^{2}\right)$. The final cell constants of $\underline{a}=7.4687(2) \AA, \underline{b}=13.4477(3) \AA, \underline{c}=20.3877(5) \AA$, volume $=2047.68(9) \AA^{3}$, are based upon the refinement of the XYZ-centroids of 488 reflections above $20 \sigma(\mathrm{I})$ with $14.26^{\circ}<2 \theta$ $<100.1^{\circ}$. Data were corrected for absorption effects using the Multi-Scan method (SADABS). The ratio of minimum to maximum apparent transmission was 0.931 . The calculated minimum and maximum transmission coefficients (based on crystal size) are 0.8730 and 0.9670 .

The structure was solved and refined using the Bruker SHELXTL Software Package, using the space group $P$ bca, with $\mathrm{Z}=8$ for the formula unit, $\mathrm{C}_{13} \mathrm{H}_{13} \mathrm{NO}_{2}$. The final anisotropic full-matrix least-squares refinement on $\mathrm{F}^{2}$ with 147 variables converged at $\mathrm{R} 1=3.35 \%$, for the observed data and $\mathrm{wR} 2=8.83 \%$ for all data. The goodness-of-fit was 1.049 . The largest peak in the final difference electron density synthesis was $0.365 \mathrm{e}^{-} / \AA^{3}$ and the largest hole was $-0.208 \mathrm{e}^{-} / \AA^{3}$ with an RMS deviation of $0.041 \mathrm{e}^{-} / \AA^{3}$. On the basis of the final model, the calculated density was $1.396 \mathrm{~g} / \mathrm{cm}^{3}$ and $\mathrm{F}(000), 912 \mathrm{e}^{-}$. 


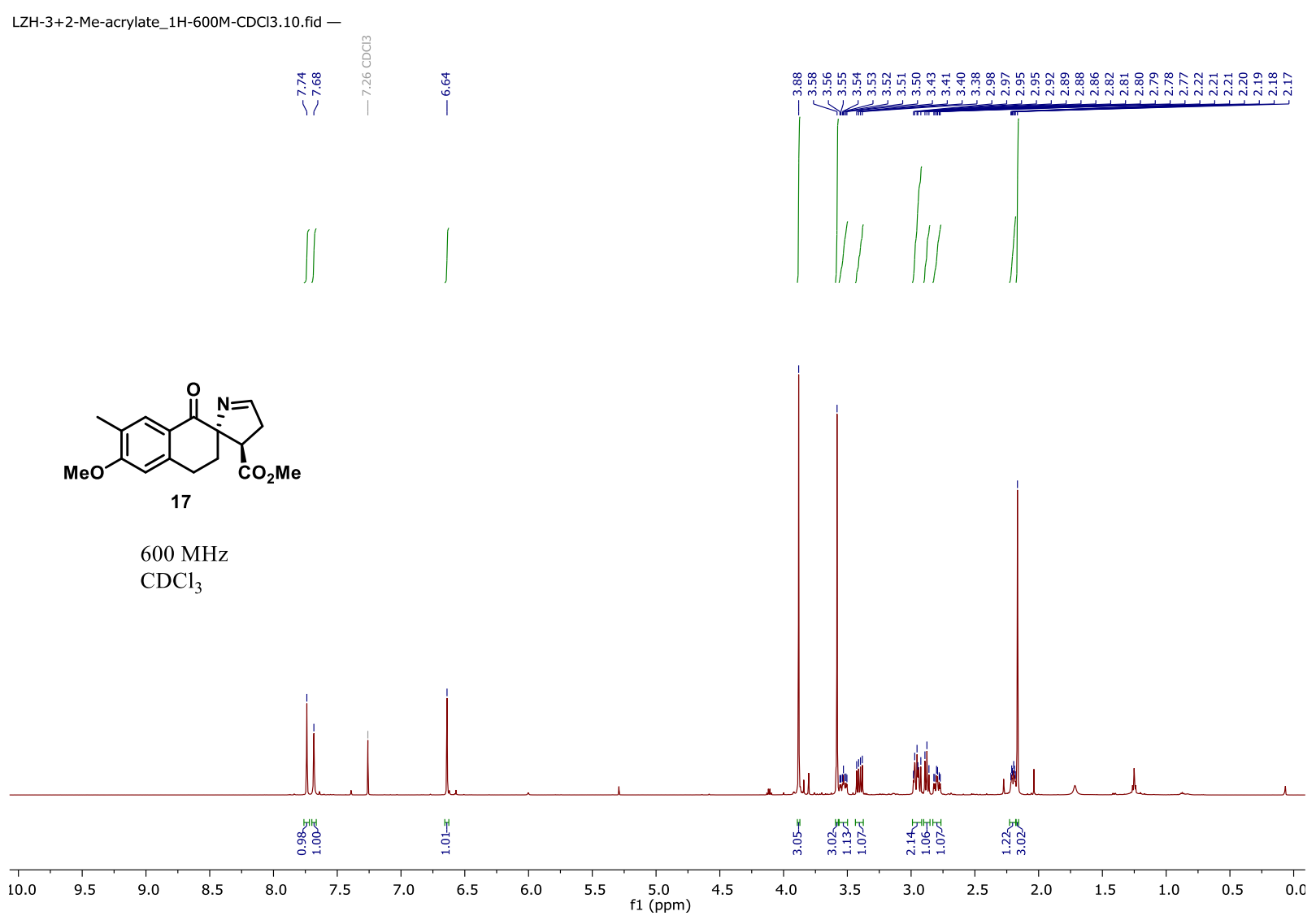

LZH-3+2-Me-acrylate_13C-600M-CDCI3.12.fid -

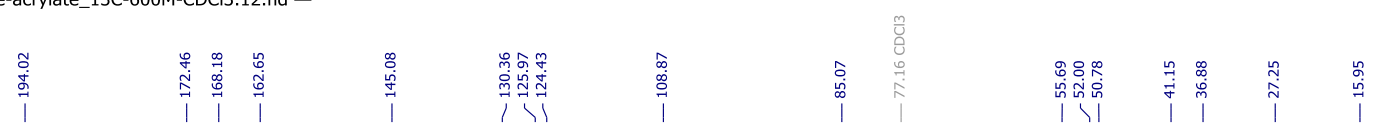

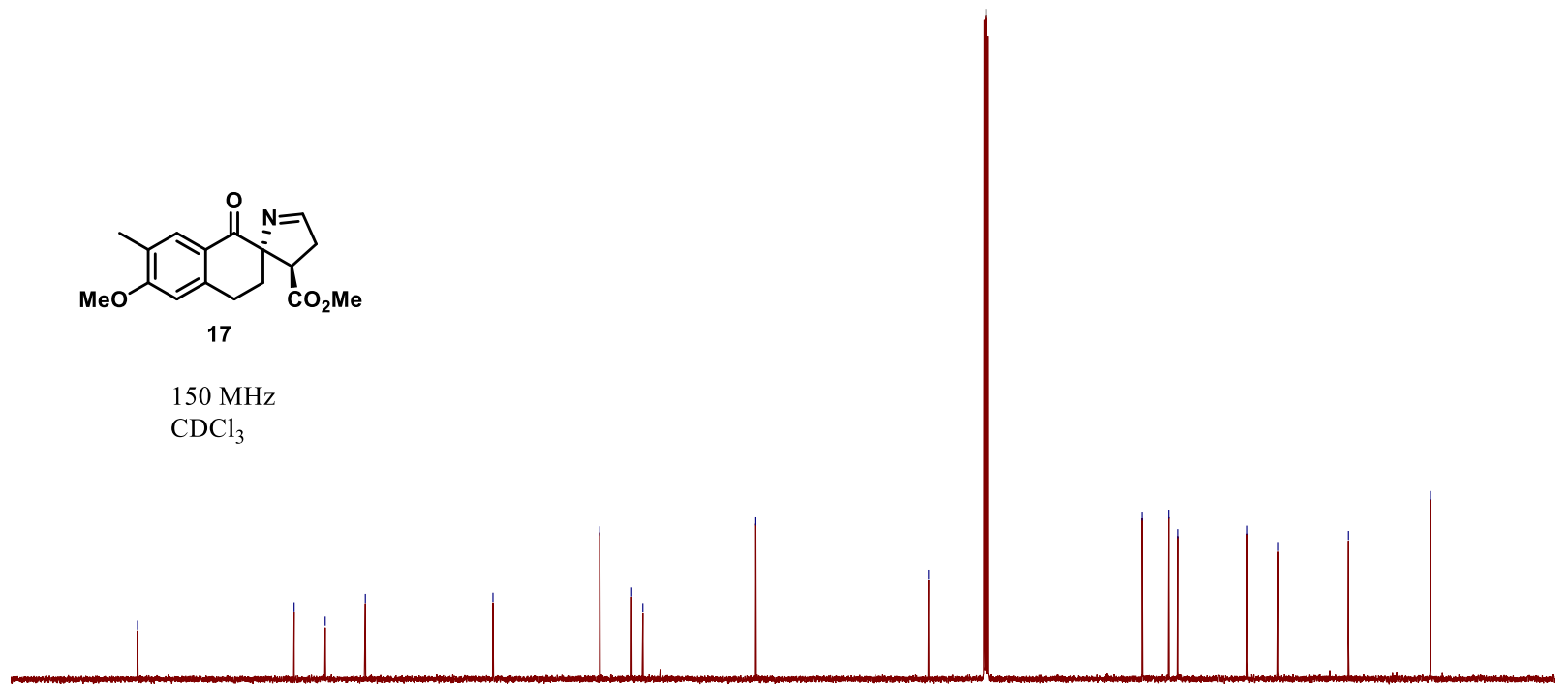

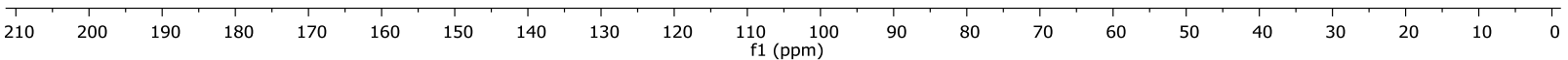




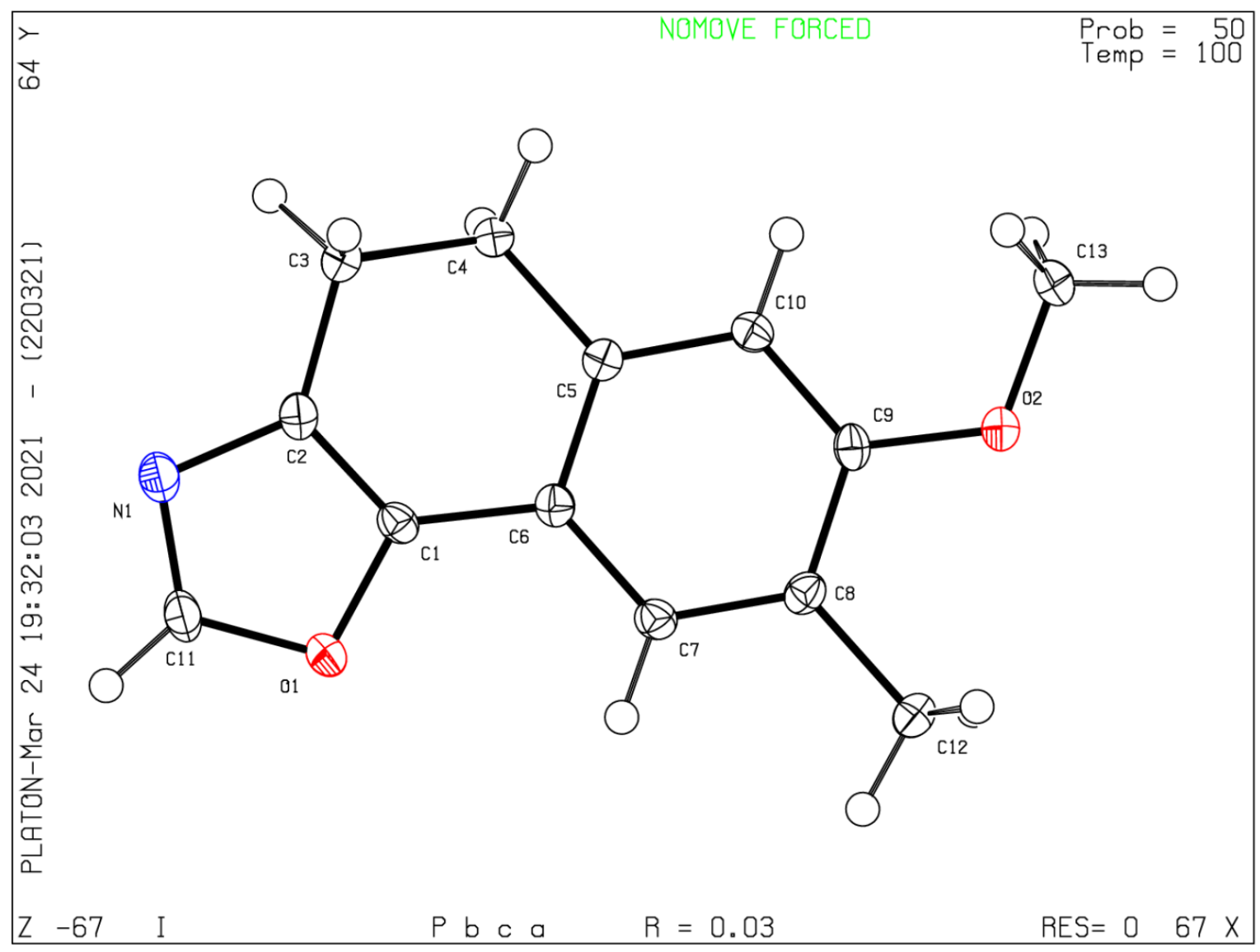


Table 1. Sample and crystal data for 21.

\begin{tabular}{|c|c|c|}
\hline Identification code & \multicolumn{2}{|l|}{ rs 106} \\
\hline Chemical formula & \multicolumn{2}{|l|}{$\mathrm{C}_{13} \mathrm{H}_{13} \mathrm{NO}_{2}$} \\
\hline Formula weight & \multicolumn{2}{|l|}{$215.24 \mathrm{~g} / \mathrm{mol}$} \\
\hline Temperature & \multicolumn{2}{|l|}{$100(2) \mathrm{K}$} \\
\hline Wavelength & \multicolumn{2}{|l|}{$1.54178 \AA$} \\
\hline Crystal size & \multicolumn{2}{|c|}{$0.044 \times 0.142 \times 0.183 \mathrm{~mm}$} \\
\hline Crystal habit & \multicolumn{2}{|l|}{ colorless plate } \\
\hline Crystal system & \multicolumn{2}{|l|}{ orthorhombic } \\
\hline Space group & \multicolumn{2}{|l|}{ Pbca } \\
\hline \multirow[t]{3}{*}{ Unit cell dimensions } & $\mathrm{a}=7.4687(2) \AA$ & $\alpha=90^{\circ}$ \\
\hline & $\mathrm{b}=13.4477(3) \AA$ & $\beta=90^{\circ}$ \\
\hline & $c=20.3877(5) \AA$ & $\gamma=90^{\circ}$ \\
\hline Volume & \multicolumn{2}{|l|}{$2047.68(9) \AA^{3}$} \\
\hline $\mathbf{Z}$ & \multicolumn{2}{|l|}{8} \\
\hline Density (calculated) & \multicolumn{2}{|l|}{$1.396 \mathrm{~g} / \mathrm{cm}^{3}$} \\
\hline Absorption coefficient & \multicolumn{2}{|l|}{$0.765 \mathrm{~mm}^{-1}$} \\
\hline $\mathbf{F}(000)$ & \multicolumn{2}{|l|}{912} \\
\hline
\end{tabular}


Table 2. Data collection and structure refinement for 21.

Diffractometer

Radiation source
Bruker D8 VENTURE

Incoatec I $\mu \mathrm{S} 3.0$ microfocus sealed tube $(\mathrm{Cu} \mathrm{K} \alpha, \lambda=1.54178$ $\AA)$

Theta range for data collection 4.34 to $80.06^{\circ}$

Index ranges

Reflections collected

Independent reflections

Coverage of independent reflections

Absorption correction

Max. and min. transmission

Structure solution technique

Structure solution program

Refinement method

Refinement program

Function minimized

Data / restraints / parameters

Goodness-of-fit on $\mathbf{F}^{2}$

$\Delta / \sigma_{\max }$

Final $\mathbf{R}$ indices

Weighting scheme

Largest diff. peak and hole

R.M.S. deviation from mean $-9<=\mathrm{h}<=9,-17<=\mathrm{k}<=15,-25<=\mathrm{l}<=25$

50833

$2240[\mathrm{R}(\mathrm{int})=0.0266]$

$99.9 \%$

Multi-Scan

0.9670 and 0.8730

direct methods

XT, VERSION 2014/5 (Sheldrick, 2015)

Full-matrix least-squares on $\mathrm{F}^{2}$

SHELXL, (Sheldrick, 2015)

$\Sigma \mathrm{w}\left(\mathrm{F}_{\mathrm{o}}^{2}-\mathrm{F}_{\mathrm{c}}^{2}\right)^{2}$

$2240 / 0 / 147$

1.049

0.001

2171 data; $\mathrm{I}>2 \sigma(\mathrm{I})$

$\mathrm{R} 1=0.0335, \mathrm{wR} 2=0.0874$

all data $\quad \mathrm{R} 1=0.0344, \mathrm{wR} 2=0.0883$

$\mathrm{W}=1 /\left[\sigma^{2}\left(\mathrm{~F}_{\mathrm{o}}^{2}\right)+(0.0404 \mathrm{P})^{2}+1.1178 \mathrm{P}\right]$

where $\mathrm{P}=\left(\mathrm{F}_{\mathrm{o}}{ }^{2}+2 \mathrm{~F}_{\mathrm{c}}{ }^{2}\right) / 3$

0.365 and $-0.208 \mathrm{e}^{-3}$

0.041 e $\AA^{-3}$ 


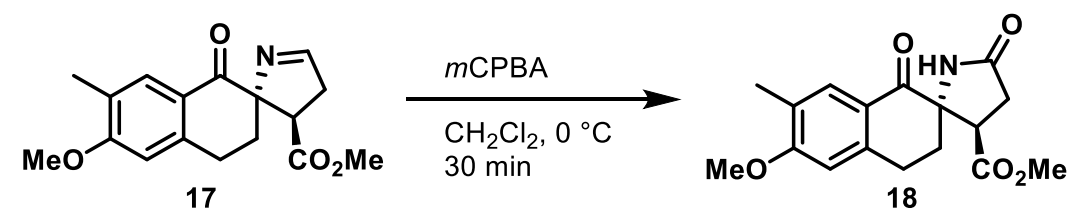

Compound 18: A solution of $17(0.213 \mathrm{~g}, 0.71 \mathrm{mmol})$ in $\mathrm{CH}_{2} \mathrm{Cl}_{2}(3.5 \mathrm{~mL})$ was cooled to $0{ }^{\circ} \mathrm{C}$. $m$ CPBA $(0.321 \mathrm{~g}, 1.41 \mathrm{mmol})$ in $\mathrm{CH}_{2} \mathrm{Cl}_{2}(3.5 \mathrm{~mL})$ was added dropwise. After the reaction stirred for $30 \mathrm{~min}$, the mixture was quenched by $10 \% \mathrm{Na}_{2} \mathrm{~S}_{2} \mathrm{O}_{3}(\mathrm{aq})$, transferred to a separatory funnel and extracted with $\mathrm{CH}_{2} \mathrm{Cl}_{2}(3 \mathrm{x})$. The organic layers were combined, washed with saturated $\mathrm{NaHCO}_{3}$ (aq) and brine, dried $\left(\mathrm{Na}_{2} \mathrm{SO}_{4}\right)$, filtered and concentrated under reduced pressure. The crude product was purified by flash chromatography on silica gel (8-18\%, ethyl acetate:hexanes) to yield the product $18(0.202 \mathrm{~g}, 90 \%)$ as white solid:

$\boldsymbol{R}_{\mathbf{f}}=0.31$ (1:3, ethyl acetate:hexanes).

Melting point $\left({ }^{\circ} \mathrm{C}\right)=130-133$.

${ }^{1} \mathbf{H}$ NMR $\left(600 \mathrm{MHz}, \mathrm{CDCl}_{3}\right) \delta=7.76(\mathrm{~s}, 1 \mathrm{H}), 6.66(\mathrm{~s}, 1 \mathrm{H}), 4.60(\mathrm{~s}, 1 \mathrm{H}), 3.90(\mathrm{~s}, 3 \mathrm{H}), 3.60-3.56$ (m, $4 \mathrm{H}), 2.94-2.86(\mathrm{~m}, 2 \mathrm{H}), 2.82-2.76(\mathrm{~m}, 2 \mathrm{H}), 2.57$ (t, $J=10.2 \mathrm{~Hz}, 1 \mathrm{H}), 2.33(\mathrm{~d}, J=13.8 \mathrm{~Hz}$, $1 \mathrm{H}), 2.18$ (s, $3 \mathrm{H})$.

${ }^{13}$ C NMR $\left(150 \mathrm{MHz}, \mathrm{CDCl}_{3}\right) \delta=192.6,172.5,163.0,145.3,130.4,126.2,124.8,109.0,80.4$, $77.1,55.8,52.1,46.6,33.2,32.3,27.0,16.0$.

IR (Diamond-ATR, neat) $\tilde{\mathrm{V}}_{\max }\left(\mathrm{cm}^{-1}\right): 2926,2949,2852,1725,1660,1600,1498,1443,1355$, 1263, 1221, 1101, 848, 753.

HRMS $(m / z)$ : calculated for $\mathrm{C}_{17} \mathrm{H}_{20} \mathrm{NO}_{5}[\mathrm{M}+\mathrm{H}]^{+} 318.1336$, found 318.1331 . 


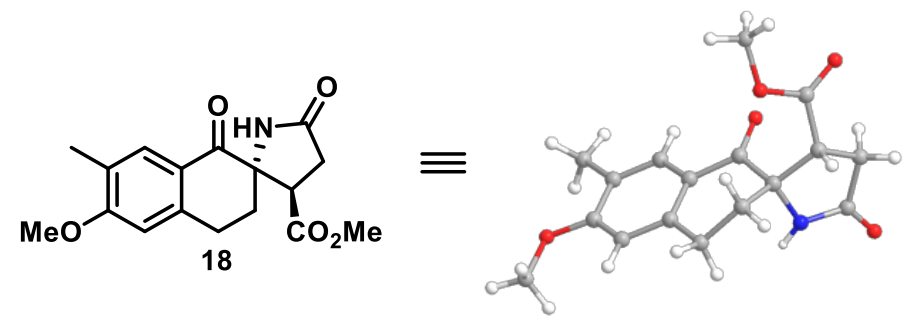

X-ray sample preparation: Compound $\mathbf{1 8}$ was prepared as saturated solution in $\mathrm{CH}_{2} \mathrm{Cl}_{2}$ in a 5 $\mathrm{mL}$ scintillation vial. This vial was put into a $20 \mathrm{~mL}$ scintillation vial which contains hexanes as same height level as $\mathrm{CH}_{2} \mathrm{Cl}_{2}$. After the $\mathrm{CH}_{2} \mathrm{Cl}_{2}$ evaporated completely, crystals formed inside of 5 $\mathrm{mL}$ vial. The crystals were a colorless plate-like specimen of $\mathrm{C}_{18} \mathrm{H}_{21} \mathrm{Cl}_{2} \mathrm{NO}_{5}$, approximate dimensions $0.068 \mathrm{~mm} \times 0.309 \mathrm{~mm} \times 0.379 \mathrm{~mm}$, was used for the X-ray crystallographic analysis. The X-ray intensity data were measured on a Bruker D8 VENTURE system equipped with a Incoatec $\mathrm{I} \mu \mathrm{S} 3.0$ microfocus sealed tube $(\mathrm{Cu} \mathrm{K} \alpha, \lambda=1.54178 \AA)$ and a multilayer mirror monochromator.

The total exposure time was 5.98 hours. The frames were integrated with the Bruker SAINT software package using a narrow-frame algorithm. The integration of the data using a monoclinic unit cell yielded a total of 42316 reflections to a maximum $\theta$ angle of $77.77^{\circ}(0.79 \AA$ resolution), of which 3936 were independent (average redundancy 10.751, completeness $=99.5 \%$, $\left.\mathrm{R}_{\text {int }}=4.40 \%, \mathrm{R}_{\text {sig }}=2.37 \%\right)$ and $3789(96.27 \%)$ were greater than $2 \sigma\left(\mathrm{F}^{2}\right)$. The final cell constants of $\underline{a}=15.1907(7) \AA, \underline{b}=12.9321(6) \AA, \underline{c}=9.4653(4) \AA, \quad \beta \quad=91.384(2)^{\circ}, \quad$ volume $=1858.89(14) \AA^{3}$, are based upon the refinement of the XYZ-centroids of 9444 reflections above $20 \sigma(\mathrm{I})$ with $5.819^{\circ}<2 \theta<154.5^{\circ}$. Data were corrected for absorption effects using the Multi-Scan method (SADABS). The ratio of minimum to maximum apparent transmission was 0.673 . The calculated minimum and maximum transmission coefficients (based on crystal size) are 0.3590 and 0.8020 .

The structure was solved and refined using the Bruker SHELXTL Software Package, using the space group P $121 / \mathrm{c} 1$, with $\mathrm{Z}=4$ for the formula unit, $\mathrm{C}_{18} \mathrm{H}_{21} \mathrm{Cl}_{2} \mathrm{NO}_{5}$. The final anisotropic fullmatrix least-squares refinement on $\mathrm{F}^{2}$ with 241 variables converged at $\mathrm{R} 1=6.30 \%$, for the observed data and $\mathrm{wR} 2=15.14 \%$ for all data. The goodness-of-fit was 1.242 . The largest peak in the final difference electron density synthesis was $0.459 \mathrm{e}^{-} / \AA^{3}$ and the largest hole was $-0.627 \mathrm{e}^{-}$ $/ \AA^{3}$ with an RMS deviation of $0.081 \mathrm{e}^{-} / \AA^{3}$. On the basis of the final model, the calculated density was $1.437 \mathrm{~g} / \mathrm{cm}^{3}$ and $\mathrm{F}(000), 840 \mathrm{e}^{-}$. 


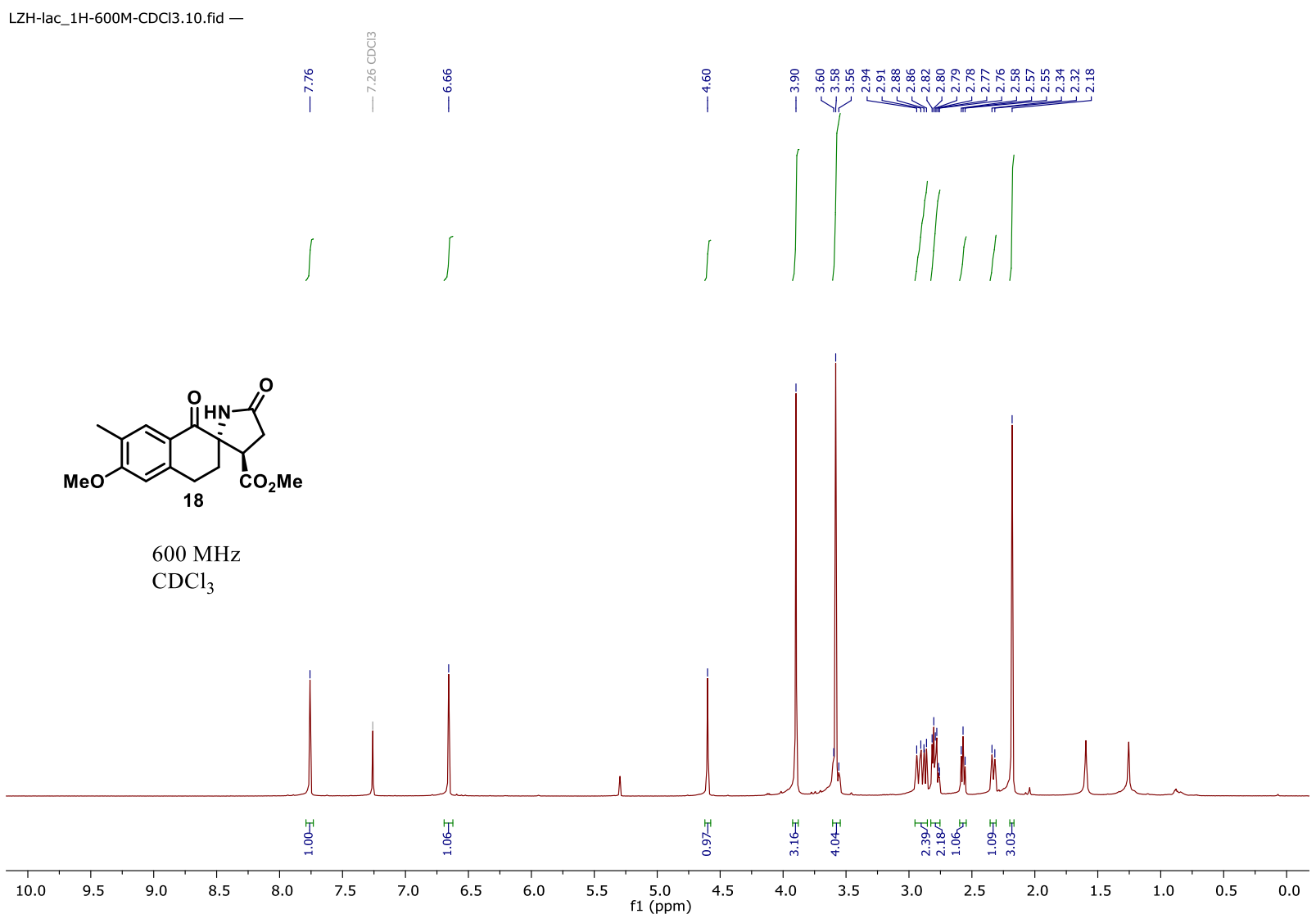

LZH-lac_13C-600M-CDCl3.12.fid -

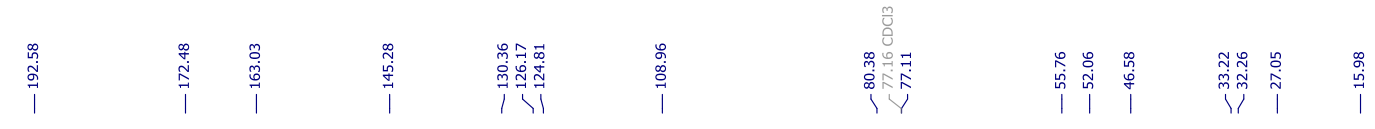

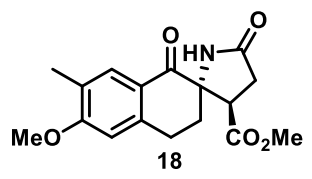

$150 \mathrm{MHz}$

$\mathrm{CDCl}_{3}$

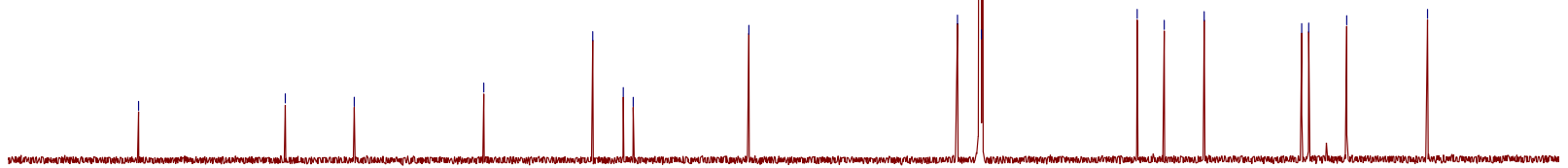

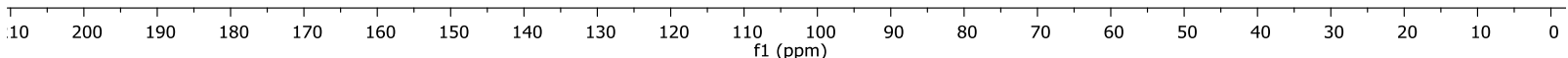




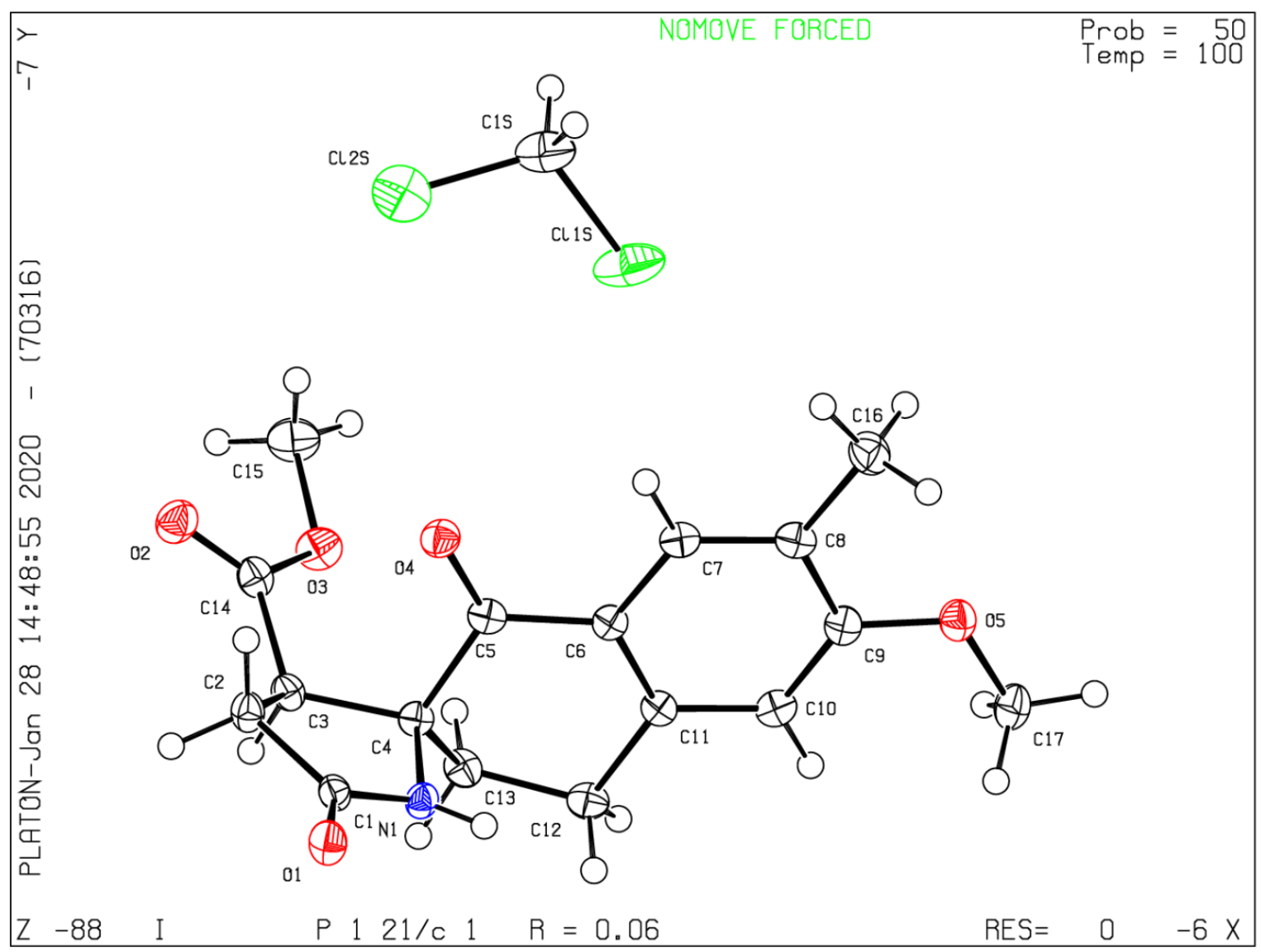


Table 3. Sample and crystal data for 18.

$\begin{array}{lll}\text { Identification code } & \text { rds } 977 \\ \text { Chemical formula } & \mathrm{C}_{18} \mathrm{H}_{21} \mathrm{Cl}_{2} \mathrm{NO}_{5} & \\ \text { Formula weight } & 402.26 \mathrm{~g} / \mathrm{mol} & \\ \text { Temperature } & 100(2) \mathrm{K} \\ \text { Wavelength } & 1.54178 \AA \\ \text { Crystal size } & 0.068 \times 0.309 \times 0.379 \mathrm{~mm} \\ \text { Crystal habit } & \text { colorless plate } & \\ \text { Crystal system } & \text { monoclinic } & \\ \text { Space group } & \mathrm{P} 121 / \mathrm{c} 1 & \\ \text { Unit cell dimensions } & \mathrm{a}=15.1907(7) \AA & \alpha=90^{\circ} \\ & \mathrm{b}=12.9321(6) \AA & \beta=91.384(2)^{\circ} \\ & \mathrm{c}=9.4653(4) \AA & \gamma=90^{\circ} \\ \text { Volume } & 1858.89(14) \AA^{3} & \\ \text { Z } & 4 \\ \text { Density (calculated) } & 1.437 \mathrm{~g} / \mathrm{cm}^{3} & \\ \text { Absorption coefficient } & 3.401 \mathrm{~mm}^{-1} & \\ \text { F(000) } & 840\end{array}$


Table 4. Data collection and structure refinement for 18.

$\begin{array}{ll}\text { Diffractometer } & \text { Bruker D8 VENTURE } \\ \text { Radiation source } & \text { Incoatec } \mathrm{I} \mu \mathrm{S} 3.0 \text { microfocus sealed } \\ \text { tube }(\mathrm{Cu} \mathrm{K} \alpha, \lambda=1.54178 \AA)\end{array}$

Theta range for data collection 2.91 to $77.77^{\circ}$

\begin{tabular}{|c|c|}
\hline Index ranges & $\begin{array}{l}-19<=\mathrm{h}<=19,-13<=\mathrm{k}<=16,- \\
11<=\mathrm{l}<=11\end{array}$ \\
\hline Reflections collected & 42316 \\
\hline Independent reflections & $3936[\mathrm{R}($ int $)=0.0440]$ \\
\hline $\begin{array}{l}\text { Coverage of independent } \\
\text { reflections }\end{array}$ & $99.5 \%$ \\
\hline Absorption correction & Multi-Scan \\
\hline Max. and min. transmission & 0.8020 and 0.3590 \\
\hline Structure solution technique & direct methods \\
\hline Structure solution program & SHELXT 2014/5 (Sheldrick, 2014) \\
\hline Refinement method & Full-matrix least-squares on $\mathrm{F}^{2}$ \\
\hline Refinement program & SHELXL-2018/3 (Sheldrick, 2018) \\
\hline Function minimized & $\Sigma \mathrm{w}\left(\mathrm{F}_{\mathrm{o}}^{2}-\mathrm{F}_{\mathrm{c}}^{2}\right)^{2}$ \\
\hline Data / restraints / parameters & 3936 / 0 / 241 \\
\hline Goodness-of-fit on $\mathbf{F}^{2}$ & 1.242 \\
\hline \multirow[t]{2}{*}{ Final $\mathbf{R}$ indices } & $\begin{array}{ll}3789 \text { data; } & \mathrm{R} 1=0.0630, \mathrm{wR} 2= \\
\mathrm{I}>2 \sigma(\mathrm{I}) & 0.1507\end{array}$ \\
\hline & $\begin{array}{l}\mathrm{R} 1=0.0645, \mathrm{wR} 2= \\
0.1514\end{array}$ \\
\hline Weighting scheme & $\begin{array}{l}\mathrm{w}=1 /\left[\sigma^{2}\left(\mathrm{~F}_{\mathrm{o}}^{2}\right)+(0.0157 \mathrm{P})^{2}+5.9994 \mathrm{P}\right] \\
\text { where } \mathrm{P}=\left(\mathrm{F}_{\mathrm{o}}^{2}+2 \mathrm{~F}_{\mathrm{c}}^{2}\right) / 3\end{array}$ \\
\hline Largest diff. peak and hole & 0.459 and $-0.627 \mathrm{e}^{-3}$ \\
\hline R.M.S. deviation from mean & $0.081 \mathrm{e}^{-3}$ \\
\hline
\end{tabular}



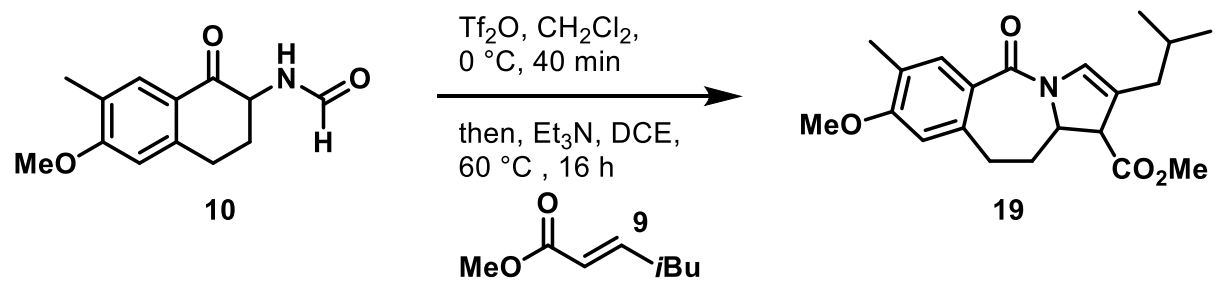

Compound 19: To a flame-dried round bottom flask was added formamide $10(0.10 \mathrm{~g}, 0.43 \mathrm{mmol})$ in anhydrous $\mathrm{CH}_{2} \mathrm{Cl}_{2}(2 \mathrm{~mL})$. The reaction was cooled to $0{ }^{\circ} \mathrm{C}$ and then $\mathrm{Tf}_{2} \mathrm{O}(0.079 \mathrm{~mL}, 0.47$ $\mathrm{mmol}$ ) was added in one portion. After stirring at $0{ }^{\circ} \mathrm{C}$ for $40 \mathrm{~min}$, the reaction was monitored by TLC for full consumption of $\mathbf{1 0}$ and concentrated under reduced pressure. Then the crude intermediate was dissolved in DCE $(0.8 \mathrm{~mL}), \mathrm{Et}_{3} \mathrm{~N}(0.012 \mathrm{~mL}, 0.085 \mathrm{mmol})$ and methyl, 5-methyl2-hexenoate $9(0.14 \mathrm{~mL}, 0.85 \mathrm{mmol})$ were added sequentially and the mixture was stirred at $60^{\circ} \mathrm{C}$ for $16 \mathrm{~h}$. The reaction was quenched by addition of saturated $\mathrm{NaHCO}_{3}(\mathrm{aq})$ and transferred to a separatory funnel, extracted with $\mathrm{CH}_{2} \mathrm{Cl}_{2}(3 \mathrm{x})$. The organic layers were combined, washed with saturated $\mathrm{NaHCO}_{3}(\mathrm{aq})$ and brine, dried $\left(\mathrm{Na}_{2} \mathrm{SO}_{4}\right)$, filtered and concentrated under reduced pressure. The crude product was purified by flash chromatography on silica gel (15-25\%, ethyl acetate:hexanes) to yield the product $19(0.075 \mathrm{~g}, 49 \%)$ as brown green waxy solid:

$\boldsymbol{R}_{\mathbf{f}}=0.28$ (1:3, ethyl acetate:hexanes).

${ }^{1} \mathbf{H}$ NMR $\left(600 \mathrm{MHz}, \mathrm{CDCl}_{3}\right) \delta=7.73(\mathrm{~s}, 1 \mathrm{H}), 7.56(\mathrm{~s}, 1 \mathrm{H}), 6.63(\mathrm{~s}, 1 \mathrm{H}), 3.87(\mathrm{~s}, 3 \mathrm{H}), 3.73(\mathrm{q}$, $J=8.4 \mathrm{~Hz} 1 \mathrm{H}), 3.55(\mathrm{~s}, 3 \mathrm{H}), 3.53-3.48(\mathrm{~m}, 1 \mathrm{H}), 2.98-2.94(\mathrm{~m}, 1 \mathrm{H}), 2.80-2.75(\mathrm{~m}, 1 \mathrm{H}), 2.45(\mathrm{~d}$, $J=9.0 \mathrm{~Hz} 1 \mathrm{H}), 2.24-2.20$ (m, $1 \mathrm{H}), 2.16(\mathrm{~s}, 3 \mathrm{H}), 1.77$ (p, $J=7.2 \mathrm{~Hz} 1 \mathrm{H}), 1.48-1.45$ (m, $2 \mathrm{H})$, $0.99(\mathrm{~d}, J=7.2 \mathrm{~Hz}, 6 \mathrm{H})$.

${ }^{13} \mathbf{C}$ NMR $\left(150 \mathrm{MHz}, \mathrm{CDCl}_{3}\right) \delta=193.8,172.4,172.0,162.6,145.0,130.4,125.9,124.4,108.8$, $85.5,58.3,55.7,51.9,51.8,42.7,37.5,27.1,26.7,23.0,22.7,15.9$.

IR (Diamond-ATR, neat) $\tilde{V}_{\max }\left(\mathrm{cm}^{-1}\right): 2947,2868,1734,1662,1598,1498,1256,1180,1099,994$, $931,775,679$.

HRMS $(\mathrm{m} / \mathrm{z})$ : calculated for $\mathrm{C}_{21} \mathrm{H}_{28} \mathrm{NO}_{4}[\mathrm{M}+\mathrm{H}]^{+} 358.2013$, found 358.2013. 


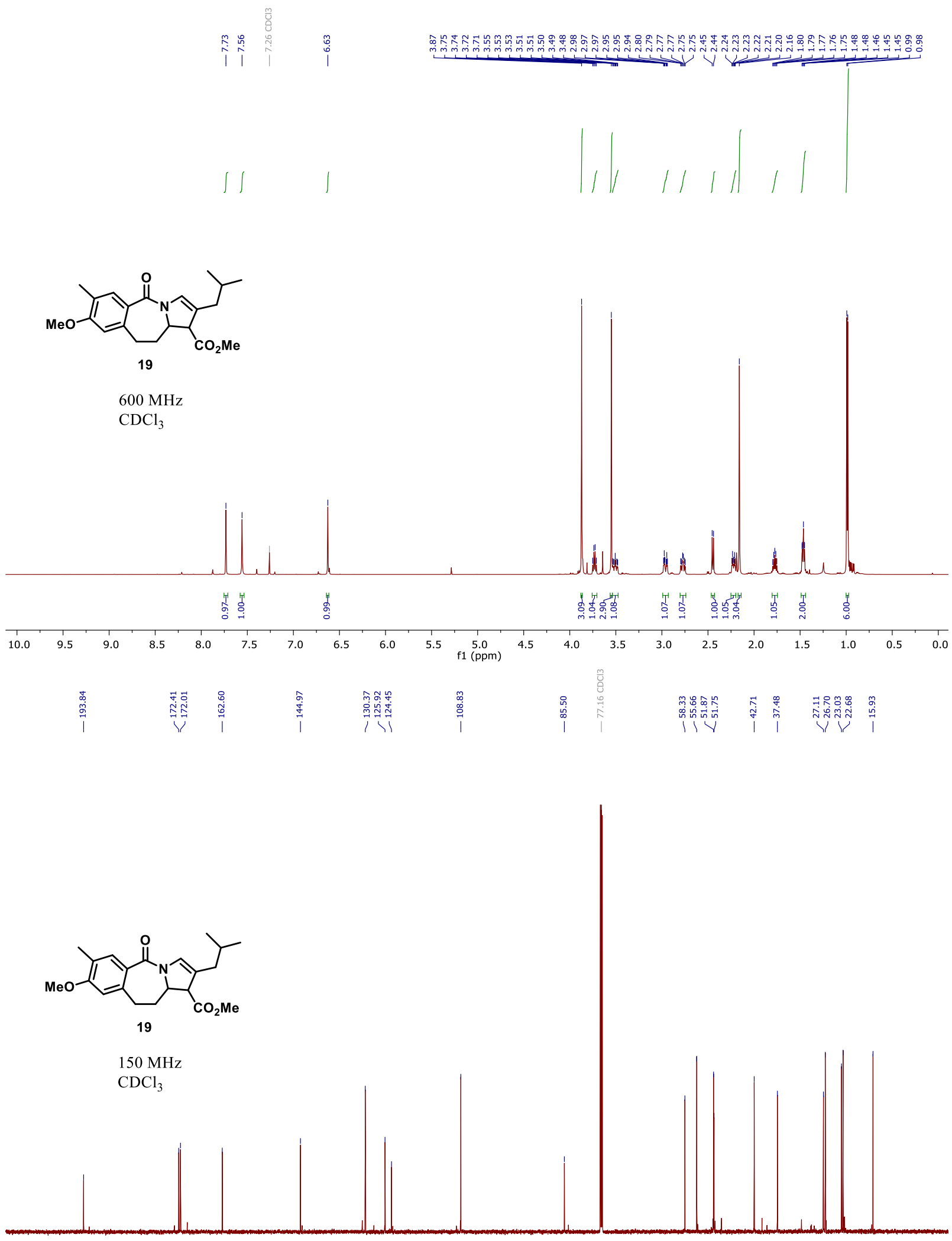

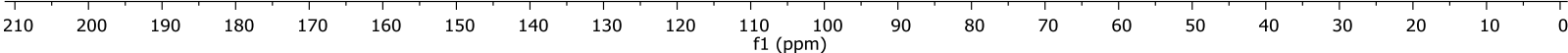




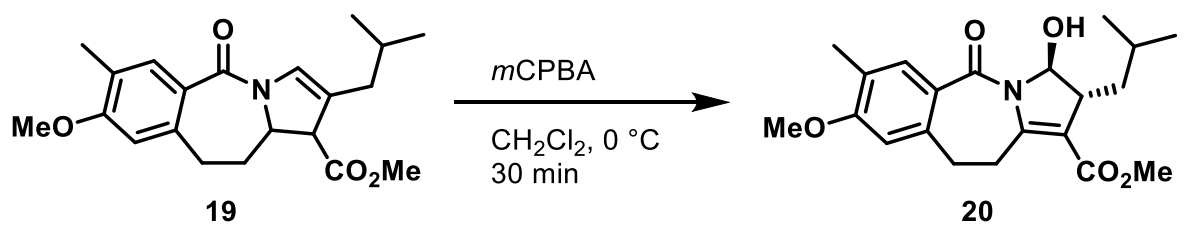

Compound 20: A solution of $19(0.050 \mathrm{~g}, 0.14 \mathrm{mmol})$ in $\mathrm{CH}_{2} \mathrm{Cl}_{2}(0.5 \mathrm{~mL})$ was cooled to $0{ }^{\circ} \mathrm{C}$. $70 \% \mathrm{mCPBA}(0.064 \mathrm{~g}, 0.28 \mathrm{mmol})$ in $\mathrm{CH}_{2} \mathrm{Cl}_{2}(1 \mathrm{~mL})$ was added dropwise. After the reaction stirred for $30 \mathrm{~min}$, the mixture was quenched by $10 \% \mathrm{Na}_{2} \mathrm{~S}_{2} \mathrm{O}_{3}$ (aq), transferred to a separatory funnel and extracted with $\mathrm{CH}_{2} \mathrm{Cl}_{2}(3 \mathrm{x})$. The organic layers were combined, washed with saturated $\mathrm{NaHCO}_{3}(\mathrm{aq})$ and brine, dried $\left(\mathrm{Na}_{2} \mathrm{SO}_{4}\right)$, filtered and concentrated under reduced pressure. The crude product was purified by flash chromatography on silica gel (4-8\%, ethyl acetate:hexanes) to yield the product $\mathbf{2 0}(0.030 \mathrm{~g}, 57 \%)$ as colorless crystals:

$\boldsymbol{R}_{\mathbf{f}}=0.32$ (1:9, ethyl acetate:hexanes).

Melting point $\left({ }^{\circ} \mathrm{C}\right)=171-175$.

${ }^{1} \mathbf{H}$ NMR $\left(500 \mathrm{MHz}, \mathrm{CDCl}_{3}\right) \delta=7.75(\mathrm{~s}, 1 \mathrm{H}), 6.64(\mathrm{~s}, 1 \mathrm{H}), 4.56(\mathrm{~s}, 1 \mathrm{H}), 3.89(\mathrm{~s}, 3 \mathrm{H}), 3.54(\mathrm{~s}, 3$ $\mathrm{H}), 3.54-3.50(\mathrm{~m}, 1 \mathrm{H}), 3.23-3.19(\mathrm{~m}, 1 \mathrm{H}), 2.95-2.90(\mathrm{~m}, 1 \mathrm{H}), 2.77-2.71(\mathrm{~m}, 1 \mathrm{H}), 2.38-2.34(\mathrm{~m}$, $1 \mathrm{H}), 2.18(\mathrm{~s}, 3 \mathrm{H}), 2.16(\mathrm{t}, J=9.5 \mathrm{~Hz} 1 \mathrm{H}), 1.87-1.78(\mathrm{~m}, 1 \mathrm{H}), 1.73-1.67(\mathrm{~m}, 1 \mathrm{H}), 1.57-1.51(\mathrm{~m}$, $1 \mathrm{H}), 1.05(\mathrm{~d}, J=6.5 \mathrm{~Hz}, 3 \mathrm{H}), 1.00(\mathrm{~d}, J=6.5 \mathrm{~Hz}, 3 \mathrm{H})$.

${ }^{13}$ C NMR (125 MHz, $\left.\mathrm{CDCl}_{3}\right) \delta=192.6,172.4,163.0,145.2,130.3,126.2,124.7,108.9,82.8$, $77.8,55.8,52.8,51.9,42.3,39.1,33.6,27.1,26.9,23.9,22.2,16.0$.

IR (Diamond-ATR, neat) $\tilde{\mathbf{V}}_{\max }\left(\mathrm{cm}^{-1}\right): 2924,2853,1741,1598,1500,1448,1352,1239,1094$, $1028,907,843,765$.

HRMS $(m / z)$ : calculated for $\mathrm{C}_{21} \mathrm{H}_{28} \mathrm{NO}_{5}[\mathrm{M}+\mathrm{H}]^{+}$374.1962, found 374.1963. 


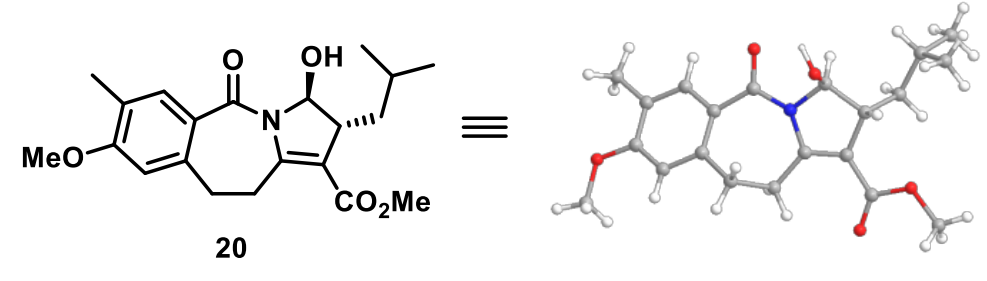

X-ray sample preparation: Compound $\mathbf{2 0}$ was prepared as saturated solution in $\mathrm{CH}_{2} \mathrm{Cl}_{2}$ in a 5 $\mathrm{mL}$ scintillation vial. This vial was put into a $20 \mathrm{~mL}$ scintillation vial which contains hexanes as same height level as $\mathrm{CH}_{2} \mathrm{Cl}_{2}$. After the $\mathrm{CH}_{2} \mathrm{Cl}_{2}$ evaporated completely, crystals formed inside of 5 $\mathrm{mL}$ vial. The crystals were colorless plate-like specimen of $\mathrm{C}_{21} \mathrm{H}_{27} \mathrm{NO}_{5}$, approximate dimensions $0.058 \mathrm{~mm} \times 0.102 \mathrm{~mm} \times 0.172 \mathrm{~mm}$, was used for the X-ray crystallographic analysis. The X-ray intensity data were measured on a Bruker D8 VENTURE system equipped with a Incoatec $\mathrm{I} \mu \mathrm{S} 3.0$ microfocus sealed tube $(\mathrm{Cu} \mathrm{K \alpha}, \lambda=1.54178 \AA)$ and a multilayer mirror monochromator.

The total exposure time was 10.11 hours. The frames were integrated with the Bruker SAINT software package using a narrow-frame algorithm. The integration of the data using a monoclinic unit cell yielded a total of 45007 reflections to a maximum $\theta$ angle of $74.55^{\circ}(0.80 \AA$ resolution), of which 3978 were independent (average redundancy 11.314, completeness $\left.=99.8 \%, R_{\text {int }}=2.79 \%, R_{\text {sig }}=1.52 \%\right)$ and $3791(95.30 \%)$ were greater than $2 \sigma\left(\mathrm{F}^{2}\right)$. The final cell constants of $\underline{a}=10.9384(6) \AA, \underline{b}=8.8234(5) \AA, \underline{c}=20.2948(7) \AA, \quad \beta=95.254(3)^{\circ}$, volume $=1950.50(17) \AA^{3}$, are based upon the refinement of the XYZ-centroids of 398 reflections above $20 \sigma(\mathrm{I})$ with $8.460^{\circ}<2 \theta<97.70^{\circ}$. Data were corrected for absorption effects using the Multi-Scan method (SADABS). The ratio of minimum to maximum apparent transmission was 0.948 . The calculated minimum and maximum transmission coefficients (based on crystal size) are 0.7149 and 0.7538 .

The structure was solved and refined using the Bruker SHELXTL Software Package, using the space group P 1 21/c 1, with $Z=4$ for the formula unit, $\mathrm{C}_{21} \mathrm{H}_{27} \mathrm{NO}_{5}$. The final anisotropic fullmatrix least-squares refinement on $\mathrm{F}^{2}$ with 252 variables converged at $\mathrm{R} 1=4.01 \%$, for the observed data and $\mathrm{wR} 2=10.19 \%$ for all data. The goodness-of-fit was 1.037 . The largest peak in the final difference electron density synthesis was $0.475 \mathrm{e}^{-} / \AA^{3}$ and the largest hole was $-0.239 \mathrm{e}^{-}$ $/ \AA^{3}$ with an RMS deviation of $0.041 \mathrm{e}^{-} / \AA^{3}$. On the basis of the final model, the calculated density was $1.272 \mathrm{~g} / \mathrm{cm}^{3}$ and $\mathrm{F}(000), 800 \mathrm{e}$. 


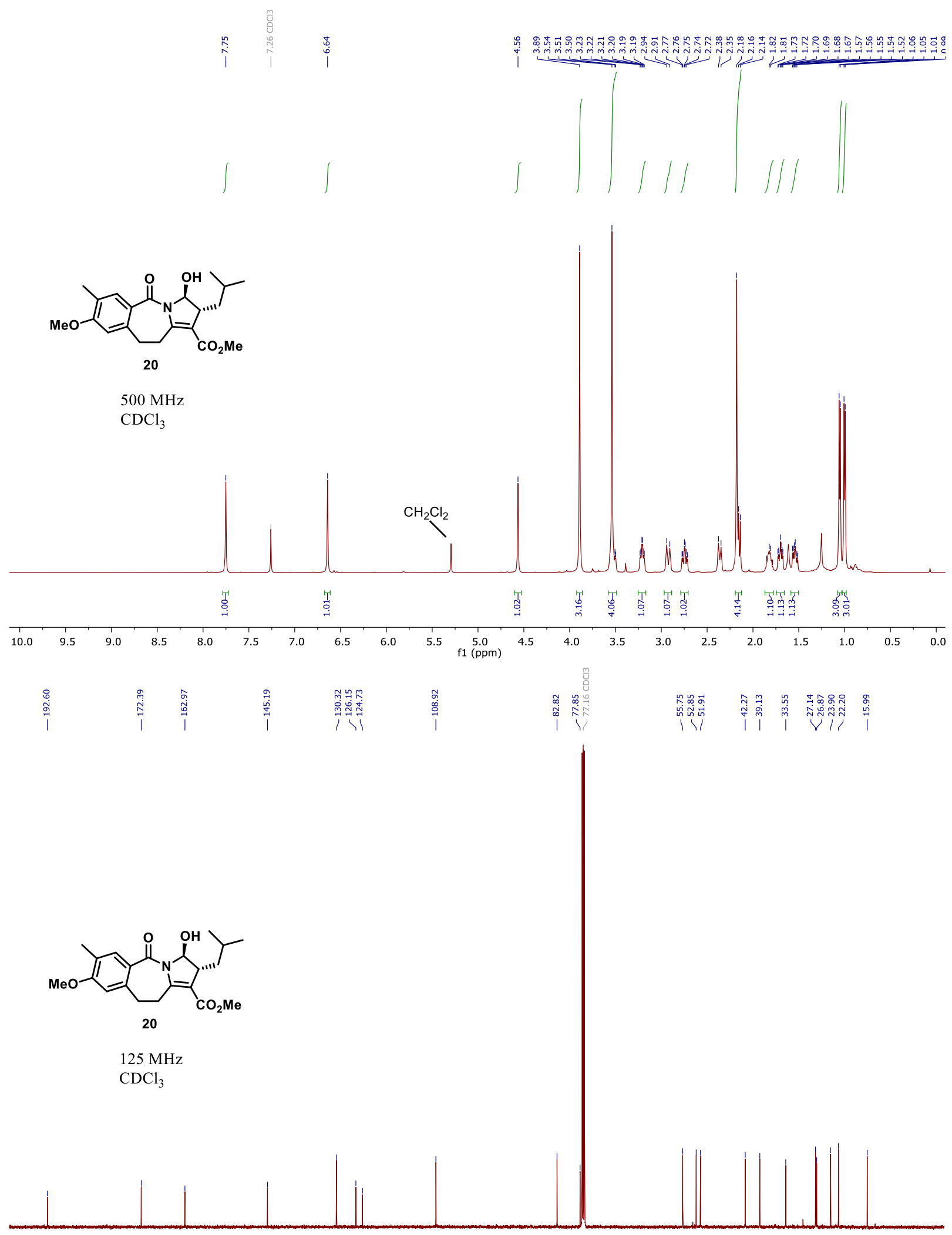

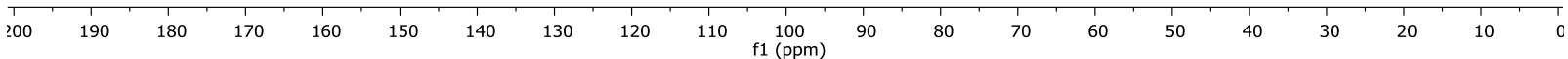




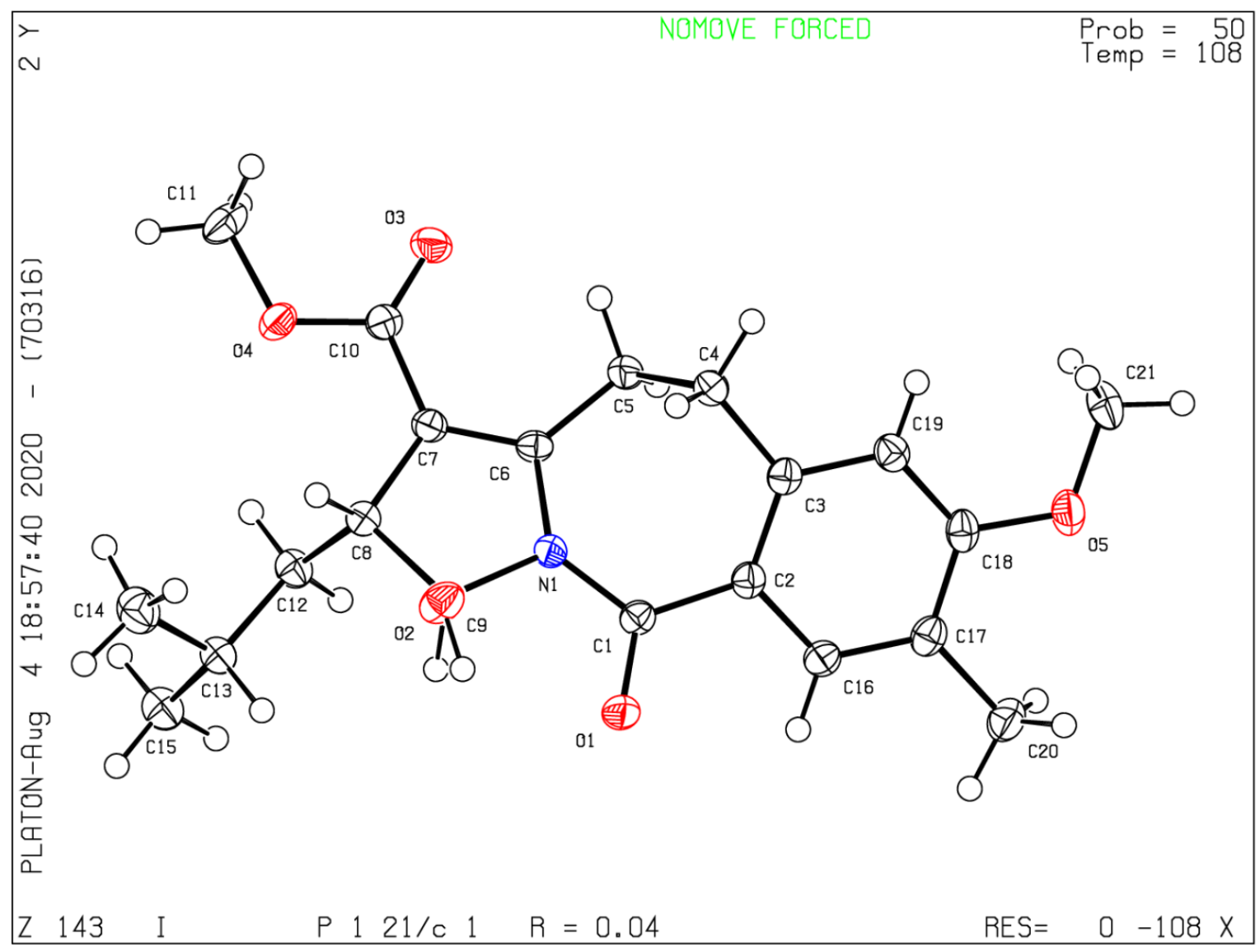


Table 5. Sample and crystal data for 20.

$\begin{array}{lll}\text { Identification code } & \mathrm{rs} 032 & \\ \text { Chemical formula } & \mathrm{C}_{21} \mathrm{H}_{27} \mathrm{NO}_{5} & \\ \text { Formula weight } & 373.43 \mathrm{~g} / \mathrm{mol} & \\ \text { Temperature } & 108(2) \mathrm{K} & \\ \text { Wavelength } & 1.54178 \AA & \\ \text { Crystal size } & 0.058 \times 0.102 \times 0.172 \mathrm{~mm} \\ \text { Crystal habit } & \text { colorless plate } & \\ \text { Crystal system } & \text { monoclinic } & \\ \text { Space group } & P 2{ }_{1} / \mathrm{c} & \\ \text { Unit cell dimensions } & \mathrm{a}=10.9384(6) \AA & \alpha=90^{\circ} \\ & \mathrm{b}=8.8234(5) \AA & \beta=95.254(3)^{\circ} \\ & \mathrm{c}=20.2948(7) \AA & \gamma=90^{\circ} \\ \text { Volume } & 1950.50(17) \AA^{3} & \\ \text { Z } & 4 & \\ \text { Density (calculated) } & 1.272 \mathrm{~g} / \mathrm{cm}^{3} & \\ \text { Absorption coefficient } & 0.738 \mathrm{~mm}^{-1} & \\ \text { F(000) } & 800\end{array}$


Table 6. Data collection and structure refinement for 20 .

Diffractometer

Radiation source

Theta range for data collection

Index ranges

Reflections collected

Independent reflections

Coverage of independent reflections

Absorption correction

Max. and min. transmission

Structure solution technique

Structure solution program

Refinement method

Refinement program

Function minimized

Data / restraints / parameters

Goodness-of-fit on $\mathbf{F}^{2}$

$\Delta / \sigma_{\max }$

Final $\mathbf{R}$ indices

Weighting scheme

Largest diff. peak and hole

R.M.S. deviation from mean
Bruker D8 VENTURE

Incoatec I $\mu$ S 3.0 microfocus sealed tube $(\mathrm{Cu} \mathrm{K} \alpha, \lambda=1.54178 \AA)$

4.38 to $74.55^{\circ}$

$-13<=\mathrm{h}<=13,-11<=\mathrm{k}<=11,-25<=\mathrm{l}<=25$

45007

$3978[\mathrm{R}(\mathrm{int})=0.0279]$

$99.8 \%$

Multi-Scan

0.7538 and 0.7149

direct methods

XT, VERSION 2014/5 (Sheldrick, 2015)

Full-matrix least-squares on $\mathrm{F}^{2}$

SHELXL-2018/3 (Sheldrick, 2015)

$\Sigma \mathrm{w}\left(\mathrm{F}_{\mathrm{o}}{ }^{2}-\mathrm{F}_{\mathrm{c}}\right)^{2}$

3978 / 0 / 252

1.037

0.001

3791 data;

$\mathrm{I}>2 \sigma(\mathrm{I})$

all data $\quad \mathrm{R} 1=0.0416, \mathrm{wR} 2=0.1019$

$\mathrm{w}=1 /\left[\sigma^{2}\left(\mathrm{~F}_{\mathrm{o}}^{2}\right)+(0.0465 \mathrm{P})^{2}+1.0962 \mathrm{P}\right]$ where $\mathrm{P}=\left(\mathrm{F}_{\mathrm{o}}{ }^{2}+2 \mathrm{~F}_{\mathrm{c}}{ }^{2}\right) / 3$

0.475 and $-0.239 \mathrm{e}^{-3}$

$0.041 \mathrm{e}^{-3}$ 
5. Synthesis of compound 7.

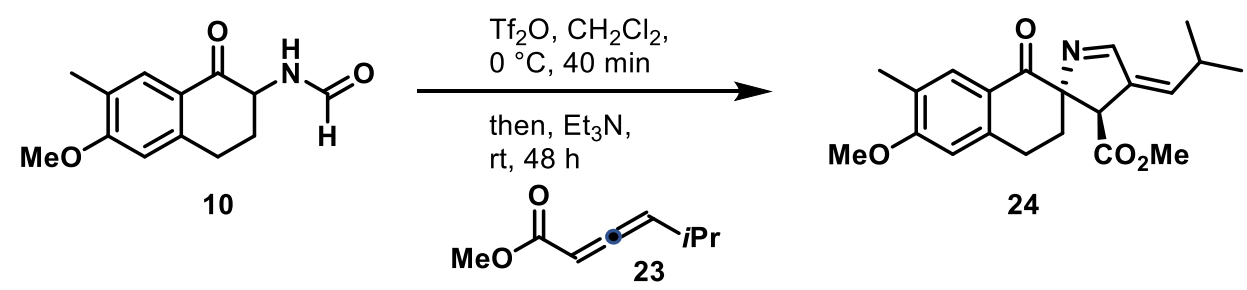

Compound 24: To a flame-dried round bottom flask was added formamide $10(1.00 \mathrm{~g}, 3.43 \mathrm{mmol})$ in anhydrous $\mathrm{CH}_{2} \mathrm{Cl}_{2}(6 \mathrm{~mL})$. The reaction was cooled to $0{ }^{\circ} \mathrm{C}$ and then $\mathrm{Tf}_{2} \mathrm{O}(0.634 \mathrm{~mL}, 3.77$ $\mathrm{mmol}$ ) was added in one portion. After stirring at $0{ }^{\circ} \mathrm{C}$ for $40 \mathrm{~min}$, the reaction was monitored by TLC for full consumption of $\mathbf{1 0}$ and concentrated the mixture to $4 \mathrm{M}$ in $\mathrm{CH}_{2} \mathrm{Cl}_{2}$. Then, $\mathrm{Et}{ }_{3} \mathrm{~N}(0.048$ $\mathrm{mL}, 0.343 \mathrm{mmol})$ and a half portion of allene $23(0.537 \mathrm{~mL}, 3.43 \mathrm{mmol})$ were added sequentially and the mixture was stirred at rt for $24 \mathrm{~h}$. The other half portion of allene $23(0.537 \mathrm{~mL}, 3.43 \mathrm{mmol})$ was added and the reaction was stirred for another $24 \mathrm{~h}$. The reaction was quenched by saturated $\mathrm{NaHCO}_{3}$ (aq) and transferred to a separatory funnel and extracted with $\mathrm{CH}_{2} \mathrm{Cl}_{2}(3 \mathrm{x})$. The organic layers were combined, washed with saturated $\mathrm{NaHCO}_{3}(\mathrm{aq})$ and brine, dried $\left(\mathrm{Na}_{2} \mathrm{SO}_{4}\right)$ filtered and concentrated under reduced pressure. The crude product was purified by flash chromatography on silica gel (25-50\%, ethyl acetate:hexanes) to yield the product $\mathbf{2 4}(0.95 \mathrm{~g}, 62 \%)$ as brown solid:

$\boldsymbol{R}_{\mathbf{f}}=0.31$ (1:1, ethyl acetate:hexanes).

${ }^{1}$ H NMR $\left(600 \mathrm{MHz}, \mathrm{CDCl}_{3}\right) \delta=7.75(\mathrm{~s}, 1 \mathrm{H}), 7.71(\mathrm{~s}, 1 \mathrm{H}), 6.60(\mathrm{~s}, 1 \mathrm{H}), 5.91\left(\mathrm{dd}, J_{1}=2.4 \mathrm{~Hz}\right.$, $\left.J_{2}=10.2 \mathrm{~Hz}, 1 \mathrm{H}\right), 3.86(\mathrm{~s}, 3 \mathrm{H}), 3.58(\mathrm{~d}, J=2.4 \mathrm{~Hz}, 1 \mathrm{H}), 3.43(\mathrm{~s}, 3 \mathrm{H}), 3.23-3.18(\mathrm{~m}, 1 \mathrm{H}), 3.13-$ $3.08(\mathrm{~m}, 1 \mathrm{H}), 2.45-2.41(\mathrm{~m}, 1 \mathrm{H}), 2.32-2.25(\mathrm{~m}, 2 \mathrm{H}), 2.15(\mathrm{~s}, 3 \mathrm{H}), 1.03(\mathrm{~d}, J=6.6 \mathrm{~Hz}, 3 \mathrm{H}), 0.98$ (d, $J=6.6 \mathrm{~Hz}, 3 \mathrm{H})$.

${ }^{13} \mathrm{C}$ NMR $\left(150 \mathrm{MHz}, \mathrm{CDCl}_{3}\right) \delta=192.9,170.9,166.5,162.3,144.1,141.6,138.4,130.3,125.9$, 124.7, 108.6, 86.0, 55.6, 52.1, 52.0, 37.2, 30.3, 26.4, 22.2, 21.6, 15.9.

IR (Diamond-ATR, neat) $\tilde{\mathrm{v}}_{\max }\left(\mathrm{cm}^{-1}\right): 2949,2861,1743,1674,1600,1267,1244,1165,1075$, $1030,901,848,782$.

HRMS $(m / z)$ : calculated for $\mathrm{C}_{21} \mathrm{H}_{26} \mathrm{NO}_{4}[\mathrm{M}+\mathrm{H}]^{+} 356.1856$, found 356.1852 . 

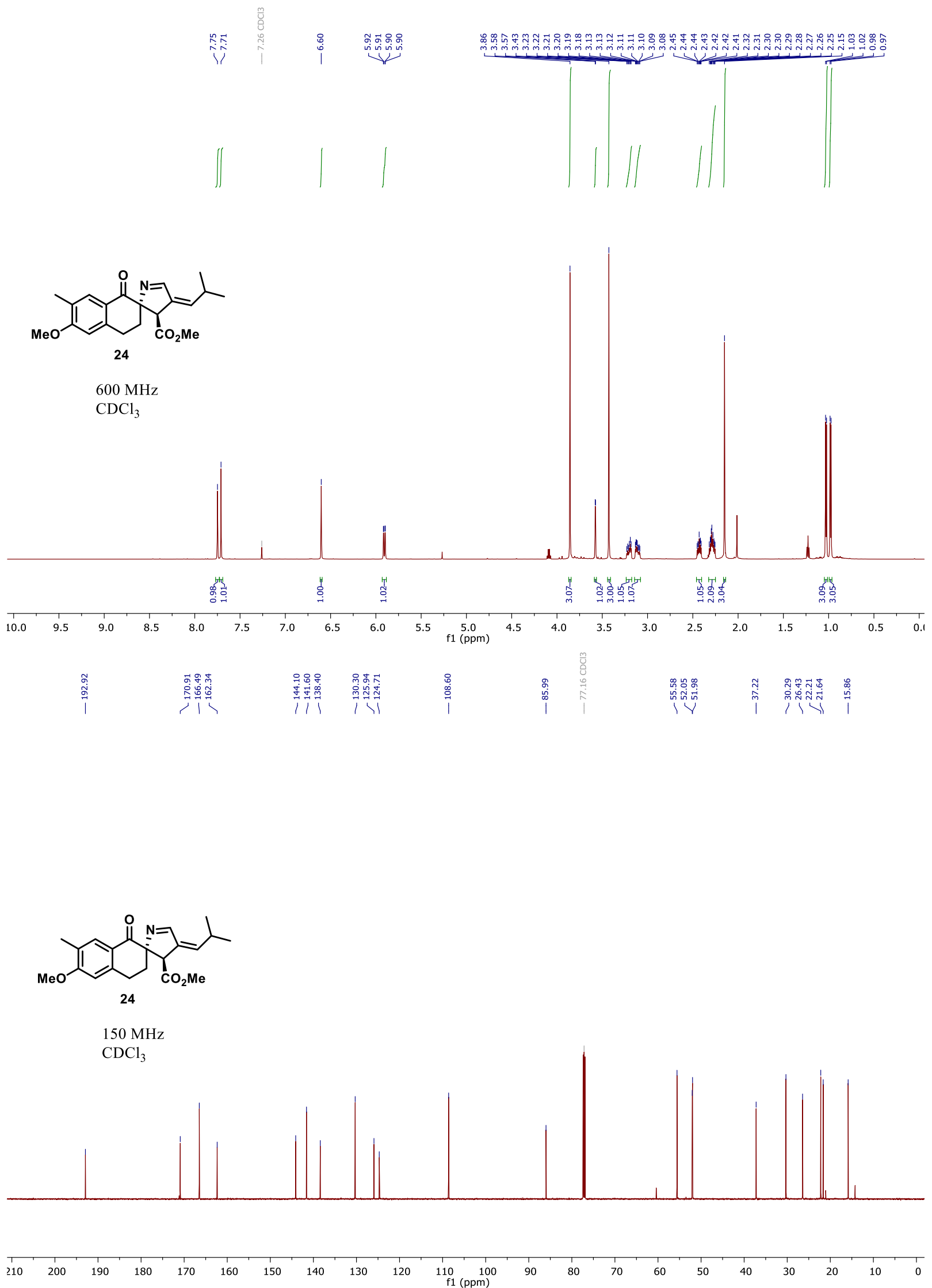


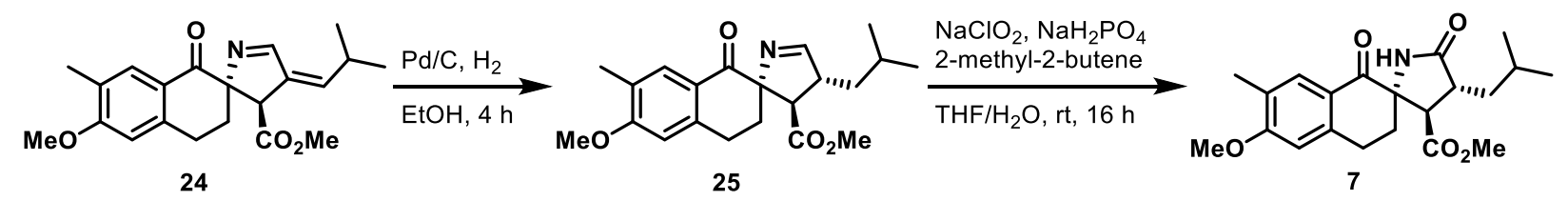

Compound 7: $10 \% \mathrm{Pd} / \mathrm{C}(0.095 \mathrm{~g}, 10 \mathrm{wt} \%)$ was added to a round bottom flask under argon atmosphere and a solution of $\mathbf{2 4}(0.950 \mathrm{~g}, 2.67 \mathrm{mmol})$ in $\mathrm{EtOH}(25 \mathrm{~mL})$ was added in one portion. The mixture was stirred under $\mathrm{H}_{2}(1 \mathrm{~atm})$. After stirring for about $4 \mathrm{~h}$, the reaction was monitored by TLC for full consumption of $\mathbf{2 4}$ and filtered with Celite, concentrated under reduced pressure to yield the crude imine $\mathbf{2 5}$, which will be used for next step without further purification. The crude 25 was dissolved in THF $(10 \mathrm{~mL}), \mathrm{NaClO}_{2}(1.51 \mathrm{~g}, 13.4 \mathrm{mmol})$ and 2-methyl-2-butene solution $(13.4 \mathrm{~mL}, 2 \mathrm{M})$ in THF were added sequentially. An aqueous solution $(3.3 \mathrm{M})$ of $\mathrm{NaH}_{2} \mathrm{PO}_{4}(1.60$ $\mathrm{g}, 13.4 \mathrm{mmol}$ ) was added dropwise to the stirred mixture over $5 \mathrm{~min}$. Then, the reaction was stirred for $16 \mathrm{~h}$, quenched with $10 \% \mathrm{Na}_{2} \mathrm{~S}_{2} \mathrm{O}_{3}(\mathrm{aq})$ and extracted by ethyl acetate $(2 \mathrm{x})$. The organic layers were combined, washed with brine, dried $\left(\mathrm{Na}_{2} \mathrm{SO}_{4}\right)$, filtered and concentrated under reduced pressure. The crude product was purified by flash chromatography on silica gel (20-40\%, ethyl acetate:hexanes) to yield the product $7(0.628 \mathrm{~g}, 63 \%)$ as pale yellow solid:

$\boldsymbol{R}_{\mathrm{f}}$ of $\mathbf{2 5}=0.56$ (1:1, ethyl acetate:hexanes), $\boldsymbol{R}_{\mathrm{f}}$ of $\mathbf{7}=0.25$ (1:1, ethyl acetate:hexanes).

Melting point $\left({ }^{\circ} \mathrm{C}\right)=212-215$.

${ }^{1} \mathbf{H}$ NMR $\left(700 \mathrm{MHz}, \mathrm{CDCl}_{3}\right) \delta=7.73(\mathrm{~s}, 1 \mathrm{H}), 6.94(\mathrm{br}, 1 \mathrm{H}), 6.58(\mathrm{~s}, 1 \mathrm{H}), 3.88(\mathrm{~s}, 3 \mathrm{H}), 3.40(\mathrm{~s}$, $3 \mathrm{H}), 3.20-3.14(\mathrm{~m}, 2 \mathrm{H}), 3.08-3.04(\mathrm{~m}, 1 \mathrm{H}), 2.81(\mathrm{~d}, J=10.5 \mathrm{~Hz}, 1 \mathrm{H}), 2.63-2.60(\mathrm{~m}, 1 \mathrm{H}), 2.29-$ $2.26(\mathrm{~m}, 1 \mathrm{H}), 2.16(\mathrm{~s}, 3 \mathrm{H}), 1.75-1.67(\mathrm{~m}, 2 \mathrm{H}), 1.29(\mathrm{p}, J=6.3 \mathrm{~Hz}, 1 \mathrm{H}), 0.87$ (dd, $J_{1}=6.0 \mathrm{~Hz}$, $\left.J_{2}=16.1 \mathrm{~Hz}, 6 \mathrm{H}\right)$.

${ }^{13} \mathbf{C}$ NMR $\left(175 \mathrm{MHz}, \mathrm{CDCl}_{3}\right) \delta=193.9,178.6,171.6,162.7,143.5,130.5,126.5,123.9,108.7$, $64.5,56.5,55.7,52.1,42.4,41.1,36.4,26.0,25.6,23.0,22.2,16.0$.

IR (Diamond-ATR, neat) $\tilde{\mathrm{v}}_{\max }\left(\mathrm{cm}^{-1}\right): 3172,3062,2947,2863,1734,1605,1494,1346,1263$, 1107, 1028, 914, 780, 668.

HRMS $(\mathrm{m} / \mathrm{z})$ : calculated for $\mathrm{C}_{21} \mathrm{H}_{28} \mathrm{NO}_{5}[\mathrm{M}+\mathrm{H}]^{+} 374.1962$, found 374.1958. 


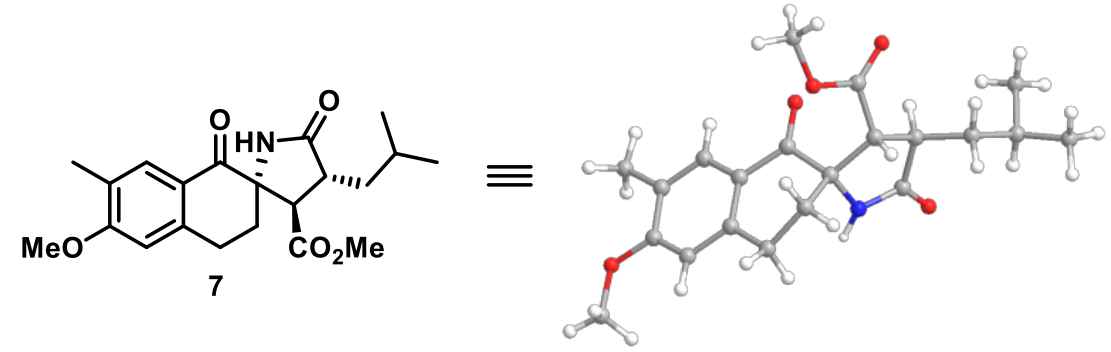

X-ray sample preparation: Compound 7 was prepared as saturated solution in $\mathrm{CH}_{2} \mathrm{Cl}_{2}$ in a $5 \mathrm{~mL}$ scintillation vial. This vial was put into a $20 \mathrm{~mL}$ scintillation vial which contains hexanes as same height level as $\mathrm{CH}_{2} \mathrm{Cl}_{2}$. After the $\mathrm{CH}_{2} \mathrm{Cl}_{2}$ evaporated completely, crystals formed inside of $5 \mathrm{~mL}$ vial. The crystals were a colorless needle-like specimen of $\mathrm{C}_{21} \mathrm{H}_{27} \mathrm{NO}_{5}$, approximate dimensions $0.037 \mathrm{~mm} \times 0.060 \mathrm{~mm} \times 0.194 \mathrm{~mm}$, was used for the X-ray crystallographic analysis. The X-ray intensity data were measured on a Bruker D8 VENTURE $\kappa$-geometry diffractometer system equipped with a Incoatec $\mathrm{I} \mu \mathrm{S} 3.0$ microfocus sealed tube $(\mathrm{Cu} \mathrm{K} \alpha, \lambda=1.54178 \AA)$ and a multilayer mirror monochromator.

The total exposure time was $5.37 \mathrm{~h}$. The frames were integrated with the Bruker SAINT software package using a narrow-frame algorithm. The integration of the data using a monoclinic unit cell yielded a total of 88942 reflections to a maximum $\theta$ angle of $74.80^{\circ}(0.80 \AA$ resolution $)$, of which 7939 were independent (average redundancy 11.203 , completeness $=99.6 \%, \mathrm{R}_{\text {int }}=7.05 \%, \mathrm{R}_{\text {sig }}=$ $2.51 \%)$ and $6389(80.48 \%)$ were greater than $2 \sigma\left(\mathrm{F}^{2}\right)$. The final cell constants of $\underline{\mathrm{a}}=11.0457(4) \AA$, $\underline{\mathrm{b}}=13.6258(5) \AA, \underline{\mathrm{c}}=26.0315(9) \AA, \beta=97.137(2)^{\circ}$, volume $=3887.6(2) \AA^{3}$, are based upon the refinement of the XYZ-centroids of 9843 reflections above $20 \sigma(\mathrm{I})$ with $6.844^{\circ}<2 \theta<159.4^{\circ}$. Data were corrected for absorption effects using the Multi-Scan method (SADABS). The ratio of minimum to maximum apparent transmission was 0.894 .

The structure was solved and refined using the Bruker SHELXTL Software Package, using the space group $P 2{ }_{1} / \mathrm{c}$, with $\mathrm{Z}=8$ for the formula unit, $\mathrm{C}_{21} \mathrm{H}_{27} \mathrm{NO}_{5}$. The final anisotropic full-matrix least-squares refinement on $\mathrm{F}^{2}$ with 503 variables converged at $\mathrm{R} 1=3.64 \%$, for the observed data and $\mathrm{wR} 2=9.54 \%$ for all data. The goodness-of-fit was 1.027 . The largest peak in the final difference electron density synthesis was $0.267 \mathrm{e}^{-/} / \AA^{3}$ and the largest hole was $-0.218 \mathrm{e}^{-} / \AA^{3}$ with an RMS deviation of $0.044 \mathrm{e}^{-} / \AA^{3}$. On the basis of the final model, the calculated density was 1.276 $\mathrm{g} / \mathrm{cm}^{3}$ and $\mathrm{F}(000), 1600 \mathrm{e}^{-}$. 


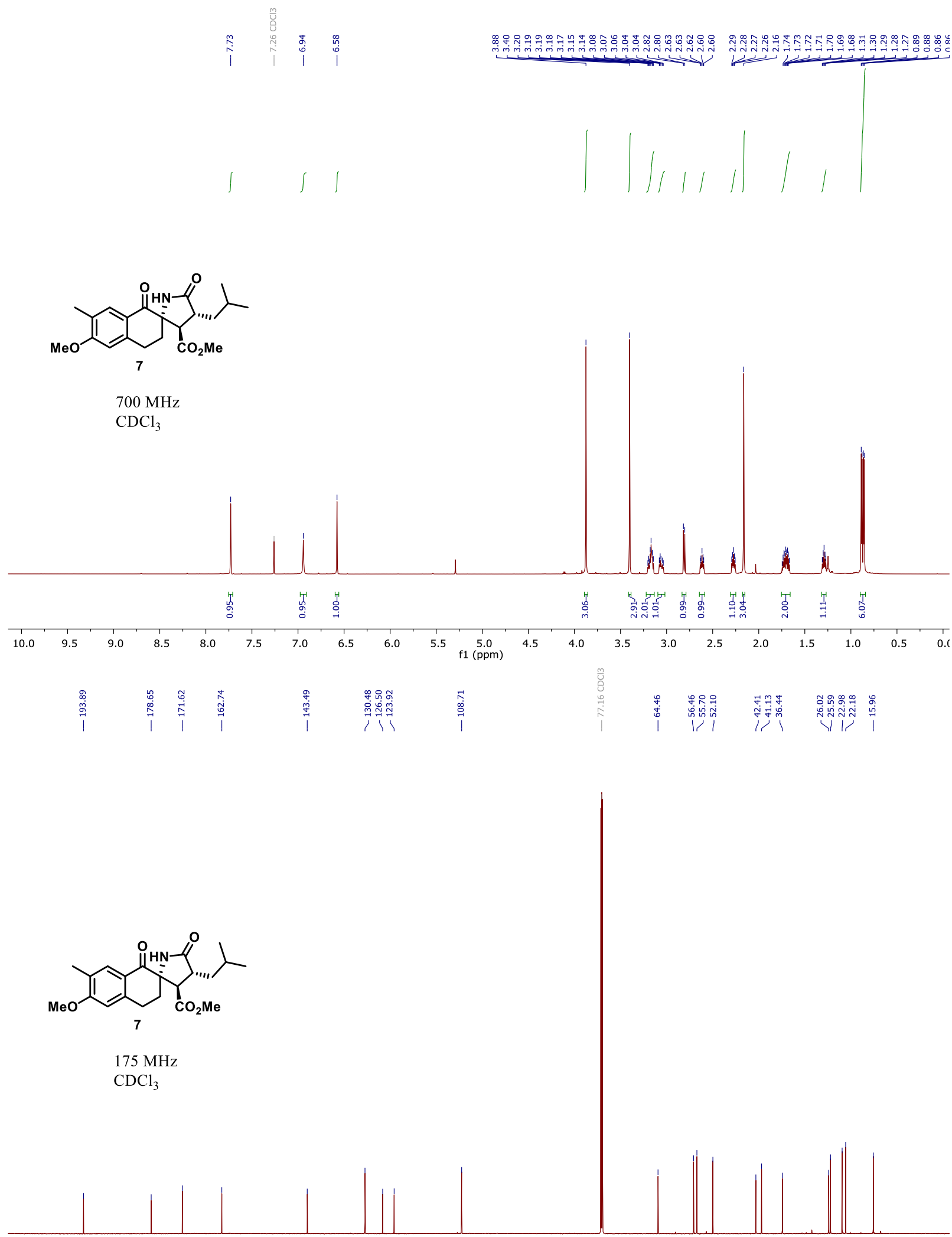

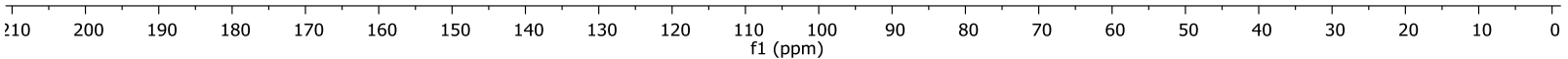




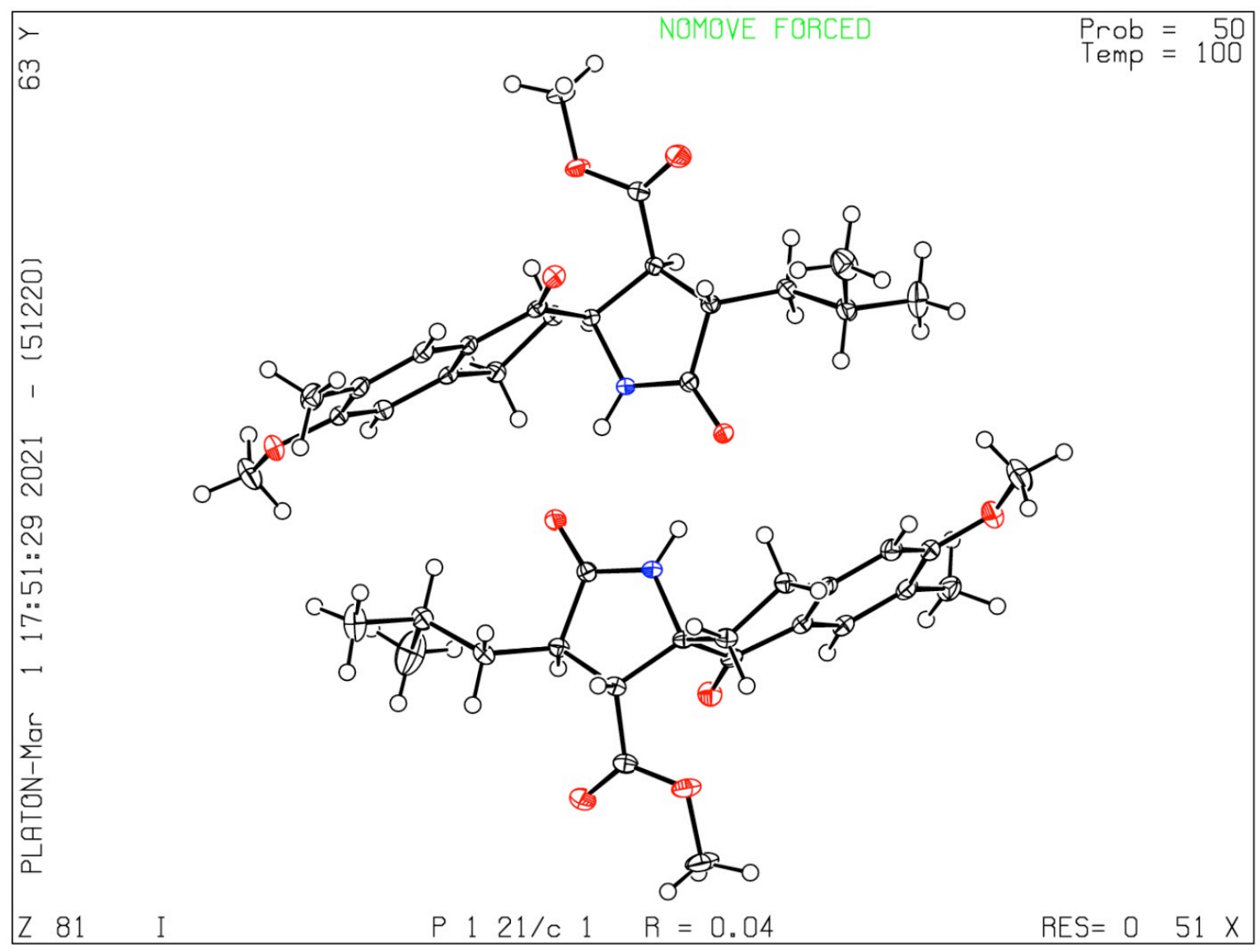


Table 7. Sample and crystal data for 7.

$\begin{array}{lll}\text { Identification code } & \mathrm{rs} 092 \\ \text { Chemical formula } & \mathrm{C}_{21} \mathrm{H}_{27} \mathrm{NO}_{5} & \\ \text { Formula weight } & 373.43 \mathrm{~g} / \mathrm{mol} & \\ \text { Temperature } & 100(2) \mathrm{K} \\ \text { Wavelength } & 1.54178 \AA \\ \text { Crystal size } & 0.037 \times 0.060 \times 0.194 \mathrm{~mm} \\ \text { Crystal habit } & \text { colorless needle } & \\ \text { Crystal system } & \text { Monoclinic } & \\ \text { Space group } & P 2{ }_{1} / \mathrm{c} & \\ \text { Unit cell dimensions } & \mathrm{a}=11.0457(4) \AA & \alpha=90^{\circ} \\ & \mathrm{b}=13.6258(5) \AA & \beta=97.137(2)^{\circ} \\ & \mathrm{c}=26.0315(9) \AA & \gamma=90^{\circ} \\ \text { Volume } & 3887.6(2) \AA^{3} & \\ \text { Z } & 8 & \\ \text { Density (calculated) } & 1.276 \mathrm{~g} / \mathrm{cm}^{3} & \\ \text { Absorption coefficient } & 0.741 \mathrm{~mm}^{-1} & \\ \text { F(000) } & 1600 & \end{array}$


Table 8. Data collection and structure refinement for 7 .

Diffractometer

Radiation source

Theta range for data collection

Index ranges

Reflections collected

Independent reflections

Coverage of independent reflections

Absorption correction

Structure solution technique

Structure solution program

Refinement method

Refinement program

Function minimized

Data / restraints / parameters

Goodness-of-fit on $\mathrm{F}^{2}$

$\Delta / \sigma_{\max }$

Final $\mathbf{R}$ indices

Weighting scheme

Largest diff. peak and hole

R.M.S. deviation from mean
Bruker D8 VENTURE $\kappa$-geometry diffractometer Incoatec $\mathrm{I} \mu \mathrm{S} 3.0$ microfocus sealed tube $(\mathrm{Cu} \mathrm{K} \alpha, \lambda=$ $1.54178 \AA$ )

3.42 to $74.80^{\circ}$

$-13<=\mathrm{h}<=13,-16<=\mathrm{k}<=16,-32<=\mathrm{l}<=32$

88942

$7939[\mathrm{R}(\mathrm{int})=0.0705]$

$99.6 \%$

Multi-Scan

direct methods

XT, VERSION 2014/5 (Sheldrick, 2015)

Full-matrix least-squares on $\mathrm{F}^{2}$

SHELXL-2018/3 (Sheldrick, 2015)

$\Sigma \mathrm{w}\left(\mathrm{F}_{\mathrm{o}}^{2}-\mathrm{F}_{\mathrm{c}}^{2}\right)^{2}$

7939 / 0 / 503

1.027

0.001

6389

data; $\quad \mathrm{R} 1=0.0364, \mathrm{wR} 2=0.0881$

$\mathrm{I}>2 \sigma(\mathrm{I})$

all data $\quad \mathrm{R} 1=0.0492, \mathrm{wR} 2=0.0954$

$\mathrm{w}=1 /\left[\sigma^{2}\left(\mathrm{~F}_{\mathrm{o}}^{2}\right)+(0.0447 \mathrm{P})^{2}+1.3700 \mathrm{P}\right]$

where $\mathrm{P}=\left(\mathrm{F}_{\mathrm{o}}{ }^{2}+2 \mathrm{~F}_{\mathrm{c}}{ }^{2}\right) / 3$

0.267 and $-0.218 \mathrm{e}^{-3}$

$0.044 \mathrm{e}^{-3}$ 